\title{
Disintegration and Trade
}

By: Jarko Fidrmuc and Jan Fidrmuc

Working Paper Number 353

November 2000 


\section{Disintegration and Trade ${ }^{*}$}

\section{Jarko Fidrmuc ${ }^{\dagger}$}

\author{
Center for European Integration \\ Studies (ZEI), University of Bonn; \\ CPB Netherlands Bureau for \\ Economic Policy Analysis, The \\ Hague; CEPR London; and William \\ Davidson Institute
}

\section{November 2000}

\footnotetext{
We benefited from comments and suggestions from Bas van Aarle, Richard E. Baldwin, Franc Klaassen, Vladimir Gligorov, Ingrid Haschke, Eduard Hochreiter, Jürgen von Hagen, and Andreas Wörgöter, as well as seminar participants at Erasmus University (Rotterdam), Center for European Integration Studies (Bonn) and the CPB Netherlands Bureau or Economic Policy Analysis (The Hague). The views expressed in this paper are those of the authors and do not represent the position of the Austrian National Bank.

$\dagger$ Oesterreichische Nationalbank, Foreign Research Division, Schwarzspanier-Str. 5, A-1090 Vienna, Austria. E-mail: Jarko.Fidrmuc@oenb.co.at; Tel.: +431 40420-5218, Fax: +431 40420-5299.

$\ddagger$ Corresponding author. Center for European Integration Studies (ZEI), University of Bonn, Walter-FlexStrasse 3, 53113 Bonn, Germany. Email: JFidrmuc@uni-bonn.de. Phone: +49-228-73-1821, Fax: +49-228-731809. Web: http://www.tbns.net/fidrmuc/.
} 


\title{
Disintegration and Trade
}

\begin{abstract}
:
The gravity model of trade is utilized to assess the impact of disintegration on trade. The analysis is based on three recent disintegration episodes involving the former Soviet Union, Yugoslavia and Czechoslovakia. The results point to a very strong home bias around the time of disintegration, with intra-union trade exceeding normal trade approximately 43 times in the former Soviet Union and Czechoslovaki, and 24 times in the former Yugoslavia. Disintegration was followed by a sharp fall in trade intensity. Nevertheless, there is a considerable hysteresis in economic relations, with trade flows among the former constituent Republics still between two and 30 times greater than normal trade in 1998.
\end{abstract}

Keywords: Gravity Model, International Trade, Disintegration

JEL Classification Numbers: F13, F15, F41 


\section{NON-TECHNICAL SUMMARY:}

Disintegration undoubtedly has an important effect on trade. Yet, the trade literature typically ponders the trade effects of integration rather than disintegration, although history tells us that countries break up more often than they unite. We use the gravity model to assess the impact of disintegration on trade among the former constituent Republics of three demised federations in Central and Eastern Europe: the Soviet Union, Yugoslavia and Czechoslovakia. For comparison, we then evaluate the effect of integration on trade-we look at German reunification, creation of preferential trade areas (PTA's) in Western and Eastern Europe, and liberalization of trade between Eastern and Western Europe.

We find that around the time of disintegration, trade flows between the constituent parts of Czechoslovakia, Soviet Union (represented here by Belarus, Russia and Ukraine) and the Baltic countries were approximately 43 times greater than normal trade (i.e. the trade corresponding to the GDPs of the respective countries and the distance between them). In contrast, the trade relations between Slovenia and Croatia were somewhat less intensive, exceeding the normal trade intensity approximately 24 times before the break-up. These results for the former federations in Eastern Europe thus indicate a very strong home bias in comparison with developed market economies. For example, McCallum (1995) finds that Canadian provinces trade 22 times more with other provinces than with US states of comparable economic size and distance. Helliwell (1997) estimates the home bias of OECD countries not sharing the same language to be on average 13 .

Disintegration was followed by a sharp fall in trade intensity in all former federations. Nonetheless, the legacy of common past remains strong. In 1998, trade relations still exceeded the normal level two times for trade between Slovenia and Croatia, seven times for the former Czechoslovakia, 13 times for the Baltics, and 30 times for Belarus, Russia and Ukraine. Such trade intensities by far surpass the effects of formal preferential trade areas. For comparison, trade within the EU and the CEFTA (Central European Free Trade Area) exceeds normal trade approximately one-and-a-half times and two times, respectively. Rose (2000) studies the trade impact of currency unions and finds that two countries using the same currency trade three times more with each other than two 
comparable countries using separate currencies. Apparently, common history is more important than formal liberalization of trade.

Compared to trade losses induced by disintegration, the gains following German reunification were less dramatic. By 1994, West German exports exceeded normal trade five times. Much of this export growth was apparently fueled by government transfers and public investments in the former German Democratic Republic. In contrast, West German imports from the former East Germany were only $77 \%$ above the normal level of trade. As such, the trade intensity between the two parts of Germany is closer to the lower bound of available estimates of home bias in developed countries.

In summary, our results suggest that although disintegration is associated with sharp deterioration of bilateral trade intensity, the relations between former constituent parts of the same federation retain some of their specific nature for several years after splitting up. The outside economic and political environment seems to matter as well. The Czech and Slovak Republics, which have better access to major Western European markets, experienced a deeper collapse of bilateral trade than the Baltics or Belarus-Russia-Ukraine, despite largely preserving the common economic area in the former Czechoslovakia. The prospects of an early EU membership for the Czech Republic, Slovenia and Estonia may have contributed to the further fall of trade with their traditional partners in the late 1990s. In contrast, trade intensity among Belarus, Russia and Ukraine actually increased in 1998, possibly as a consequence of the Russian crises, and efforts towards re-unification between Russia and Belarus. Hence, while disintegration matters, the overall context is important as well. 


\section{Introduction}

Many papers and monographs have been written recently about economic aspects and consequences of integration. This surge of interest reflects the slow but steady intensification of integration processes in Western Europe and elsewhere. Yet, history tells us that countries break up much more often than they unite. The number of countries on the face of the Earth increased more than three-fold during the last century. The economic consequences of disintegration are undoubtedly substantial, even when the break-up is peaceful. However, very little research has been done to assess the costs of disintegration.

In this paper, we attempt to fill this gap, by looking at three recent disintegration episodes in Europe. We use the gravity model to assess the impact of disintegration on trade among the former constituent Republics of three demised federations in Central and Eastern Europe: the Soviet Union (we look separately on the Baltic countries on the one hand, and Belarus, Russia and Ukraine on the other hand), Yugoslavia and Czechoslovakia. For comparison, we then evaluate the effect of integration on trade-we look at German reunification, creation of preferential trade areas (PTA's) in Western and Eastern Europe, and liberalization of trade between Eastern and Western Europe.

The gravity model, in an analogy to the Theory of Gravity in Physics, relates the trade between a pair of countries to their economic mass, measured by their respective GDPs, and the distance between them. The non-standard nature of trade relations is identified by means of dummies for pairs or groups of countries of interest-a positive coefficient implies above-normal, or preferential, trade relations whereas a negative coefficient indicates below-normal, or discriminatory, trade relations. We estimate the gravity model with trade flows among the OECD countries and selected Central and Eastern European countries. By estimating the gravity equation separately for each year between 1990 and 1998, we are able to observe the evolution of trade patterns over time. We are particularly interested in the evolution of bilateral trade within former federations in the wake of disintegration.

We find that around the time of disintegration, trade flows between the constituent parts of Czechoslovakia, Soviet Union (represented here by Belarus, Russia and Ukraine) and the Baltic countries were approximately 43 times greater than normal trade (i.e. the trade 
corresponding to the GDPs of the respective countries and the distance between them). In contrast, the trade relations between Slovenia and Croatia were somewhat less intensive, exceeding the normal trade intensity approximately 24 times at the time of the break-up. The result for the former Soviet Union, the Baltics and the former Czechoslovakia thus indicates a very strong home bias in comparison with developed market economies. For example, McCallum (1995) finds that Canadian provinces trade 22 times more with other provinces than with US states of comparable economic size and distance. Wolf (1997) estimates a similar tendency for 'excessive' trade within the federal states in the US. Helliwell (1997) estimates the home bias of OECD countries not sharing the same language to be on average 13. Similarly, Head and Mayer (2000) estimate that an average EU country purchases 14 times more from domestic producers than from equally distant foreign ones. Nitsch (1998) estimates the home bias for EU counties as 7 on average and ranging between 1.8 for the Netherlands and 68 for Portugal. Obstfeld and Rogoff (2000) provide a recent survey of estimates of the home bias in several countries.

Disintegration was followed by a sharp fall in trade intensity in all former federations. Nonetheless, the legacy of common past remains strong. In 1998, trade relations still exceeded the normal level two times for trade between Slovenia and Croatia, seven times for the former Czechoslovakia, 13 times for the Baltics, and 30 times for Belarus, Russia and Ukraine. Such trade intensities by far surpass the effects of formal preferential trade areas. For comparison, our findings indicate that trade within the EU and the CEFTA (Central European Free Trade Area) exceeds normal trade approximately one-and-a-half times and two times, respectively. Rose (2000) studies the trade impact of currency unions and finds that two countries using the same currency trade three times more with each other than two comparable countries using separate currencies. Apparently, the common history is more important than formal liberalization of trade, although in the case of the Baltics and Belarus-Russia-Ukraine, the continuing home bias can be partially attributed also to their relative geographical isolation.

To our knowledge, the effects of disintegration on trade received little attention in previous literature. This is probably due to lack of reliable data as well as lack of suitable disintegration episodes. The main exceptions are De Ménil and Maurel (1994) who use the 
gravity model to assess the trade effects of the disintegration of Austro-Hungarian Empire in 1918 Cheikbossian and Maurel (1998) who analyze the break-down of the CMEA and Djankov and Freund (2000) who estimate home bias for trade among selected Russian regions before the onset of economic reforms (1987-1990) and for a few years after the disintegration of the Soviet Union in 1992 (1994-1996).

Instead, most of the literature is concerned with the trade effect of integration, usually taking the form of free-trade areas and customs unions (see, for example, Bayoumi and Eichengreen, 1995, and Soloaga and Winters, 1999) or currency unions (Rose, 2000). Yet, it is difficult to distinguish the impact of a preferential-trade area from hysteresis in trade. As Eichengreen and Irwin (1996,) point out, formal integration usually follows above-standard trade relations in the past. By focusing on disintegration episodes in the time dimension, we are able to observe and evaluate the changes in trade patterns in the wake of disintegration. We find that although there is considerable hysteresis in trade relations after disintegration, the fall in trade intensity is substantial.

The next section describes the gravity model and discusses the main methodological issues. Section 3 describes the data. Sections 4, 5 and 6 present the results of our empirical analysis for former federations in Eastern Europe, German reunification, and formal preferential trade areas, respectively. The last section summarizes our conclusions.

\section{The Gravity Model}

The gravity model (Linnemann, 1966, and Linder, 1961) relates the trade flows between two countries to the importer's demand, the exporter's supply and the costs of engaging in trade. The importer's demand and the exporter's supply are proxied by aggregate outputs of the two countries (in addition, some studies use also the output per capita and/or the land area). Trade costs (transport and transaction costs) are proxied by geographical distance, typically measured as the distance between the capital cities of the two countries. Some studies use also measures of remoteness (see Smarzynska, 1999).

Although the gravity model of trade is commonly used to assess trade patterns between countries or within preferential trade areas, its theoretical underpinnings are ambiguous, and were only developed after the model had proven successful in empirical analysis. Helpman 
and Krugman (1985) formulate the gravity relation in a model with differentiated products and increasing returns to scale. On the other hand, Deardorff (1995) derives the gravity model in the framework of the Heckscher-Ohlin model and concludes that the gravity model characterizes many models and, therefore, it cannot be used for testing trade theories. Evenett and Keller (1998) find empirical support for formulations of the gravity model based on both the Heckscher-Ohlin model and increasing returns to scale.

We estimate the gravity model in the following form:

$$
M=\beta_{1}+\beta_{2} Y_{M}+\beta_{3} Y_{X}+\beta_{4} d+\sum_{k} \beta_{k} D_{k}+\varepsilon,
$$

where $M$ stands for bilateral imports, ${ }^{1} Y$ is the GDP of the exporting and the importing countries (denoted by $X$ and $M$, respectively), $d$ is the distance between the capital cities of both countries, ${ }^{2}$ and $\varepsilon$ is the disturbance term. All these variables are in logs. In line with the terminology common for the literature using the gravity model, we refer to the level of trade as predicted by the countries' economic sizes and distance as normal or potential trade. The intensity of non-standard trade relations is measured by means of dummy variables, $D_{k}$, for specific pairs or groups of countries. A positive coefficient estimate implies abovenormal or preferential trade relations whereas a negative coefficient estimate, in contrast, implies below-normal or discriminatory trade pattern.

We include dummies to capture three types of trade relations. First, sharing a common border or common language reduces transaction costs. Therefore, we use a dummy for countries sharing a common border, and a dummy for English speaking countries. We do not include dummies for other languages as most of the other countries (out of those included in our data set) sharing a language also share borders. ${ }^{3}$ Since the effect of language

\footnotetext{
${ }^{1}$ For various reasons, the data on bilateral trade flows as reported by the two respective countries often differ. To ensure consistency, we use trade flows as reported by the importing country.

${ }^{2}$ We are grateful to Holzmann and Zukowska-Gagelmann (1996) for sharing with us their distance matrix. As in their paper, we use the center of a triangle defined by Frankfurt, Munich, and Berlin rather than the capital as the reference point for Germany.

${ }^{3}$ For example, Austria, Germany and Switzerland, Belgium and France, or Belgium and the Netherlands. The main exception is Canada and France having both French as their official language without having a common border.
} 
on trade is not our primary interest, we allow for the common-language effect to be picked up by the border dummy in these cases.

Second, we use dummies for formal preferential trade areas in Europe. Specifically, we include dummies for the European Union (the 12 countries that formed the EU before the last enlargement, denoted henceforth as the EU12), the EFTA, the CEFTA (Czech Republic, Hungary, Poland, Slovakia and Slovenia), the last EU enlargement round (distinguishing trade flows between the EU12 and Austria, Finland, and Sweden, henceforth EFTA3), and the Europe Agreements between the EU and the associated countries. ${ }^{4}$ To capture the evolution of trade relations, we use the same set of dummies for the entire period, i.e. also before the formal agreement was concluded. Finally, we include dummies for the successor states of former federations in Central and Eastern Europe. Because of problems with availability and reliability of the data, we are unable to include all former Republics of the Soviet Union and Yugoslavia. Therefore, we analyze trade patterns only among the Baltic countries, Belarus-Russia-Ukraine, and Slovenia-Croatia. We consider the Baltics separately from the rest of the former Soviet Union because of their specific historical and political background.

\section{Data}

Our data contain bilateral trade flows for OECD countries (excluding Iceland, Mexico and Korea), and selected Central and Eastern European countries. As we are interested in the evolution of trade relations during the processes of integration and disintegration that occurred during the last decade, we estimate equation (1) for each of the nine available years from 1990 to 1998 . This data set provides between 600 and 1300 bilateral trade flows. The sample size changes because of data availability and especially because new countries emerged in Eastern Europe during the analyzed period. The data for Bulgaria, Hungary, Poland and Romania span the entire period. The trade data for Belarus, Croatia, Estonia, Latvia, Lithuania, Russia, Slovenia, and Ukraine start as of 1992, and those for the Czech Republic and Slovakia start as of 1993. I addition, we use estimates of predisintegration trade flows between the Czech and Slovak Republics (1991-93) and Slovenia

\footnotetext{
${ }^{4}$ Bulgaria, Czech Republic, Estonia, Hungary, Latvia, Lithuania, Poland, Romania, Slovakia and Slovenia.
} 
and Croatia (1990), as described below. The source of data on trade flows and aggregate outputs is the IMF (Direction of Trade for trade flows and International Financial Statistics for GDP). Missing data on aggregate output for some CEECs were taken from the EBRD Transition Report 1998.

Bilateral trade flows between constituent parts of former federations such as the Soviet Union, Yugoslavia, and Czechoslovakia were typically not officially reported, and therefore an assessment of the intensity of trade relations prior to the break-up is difficult. ${ }^{5}$ An exception is the trade between the Czech and Slovak Republics, where alternative data are available for 1991-1993, the two years before the break-up and the first post break-up year. These data are based on enterprise reports of deliveries between the two Republics. ${ }^{6}$ Two caveats apply to these data. First, they are based on enterprise reports, not customs statistics. Second, they include only deliveries of enterprises with 25 and more employees. Therefore, these data are not necessarily directly comparable with the official statistics. Nevertheless, the estimates obtained for 1993 based on the two types of data are almost identical and not statistically significantly different from each other. Therefore, we believe it is instructive to use these data to assess the trade intensity before break-up.

Similar data have been reported for Slovene trade with the other former federal Republics of Yugoslavia. According to Mencinger (1998), the rest of Yugoslavia accounted for $57.7 \%$ and $58.7 \%$ of Slovenia's total exports and imports in 1990, respectively. Croatia was the most important trade partner ( $28.8 \%$ of both exports and imports) within the former federation. Stiblar (1996) reports a similar trade structure for Slovenia at the end of the 1980s. Based on this figures, along with estimates of Slovenia's total trade (without

\footnotetext{
5 According to Djankov and Freund (2000), inter-republic trade flows were not reported for the former Soviet Union between 1990 and 1993. Boss and Havlik (1994) report several estimates of trade flows among selected FSU countries at the beginning of the 1990s. However, these data are hardly comparable to later trade flows due to high inflation rate in the successor countries. Furthermore, the range of their estimates makes any comparisons questionable, although they generally confirm a significant decline of trade.

${ }^{6}$ The sources of the data are: Vzajomne dodavky medzi SR a CR: 1.-4. stvrtrok 1992, Statistical Office of the Slovak Republic, 1993; and Predaj tovarov medzi SR a CR v roku 1993 podla stvrtrokov, Statistical Office of the Slovak Republic, 1994.
} 
the rest of former Yugoslavia) reported by WIIW (1999), we are able to estimate the trade flows between Slovenia and Croatia in 1990, one year before independence.

Finally, we compare the trade development in these countries to trade between West Germany and the former German Democratic Republic. Our data are based on German Statistical Office's reports of trade flows (including services) between both German regions from 1992 to $1994 .^{7}$

\section{Trade Effects of Disintegration}

The number of observations ${ }^{8}$ in our dataset nearly doubles between 1990 and 1998 as new countries arise from the ruins of the Soviet Union, Yugoslavia, and Czechoslovakia. The inclusion of additional observations might affect the results. Therefore, we estimate the gravity model as defined by (1) first on a sample of 630 original observations of bilateral trade flows, which are available throughout the entire period from 1990 to 1998 . We will refer to this data subset as the restricted sample, and the results are reported in Table 1. Then, we estimate the gravity model on the full sample, containing also observations for the newly created countries. The results for the full sample are reported in Table 2 . The last set of results makes use of alternative estimates of trade between the Czech and Slovak Republics, Slovenia and Croatia, and the two parts of Germany. For the sake of comparability, the results based on these alternative data sources are reported separately in Table 3. We estimate a separate equation for each year between 1990 and 1998 in order to be able to observe the evolution of trade relations over time.

\section{Insert Tables 1-3 about here.}

The gravity model gives very good explanation of trade patterns as evidenced by the high values of adjusted $\mathrm{R}^{2}$, all exceeding 0.8 . As expected, the effect of distance is negative

\footnotetext{
${ }^{7}$ See Vierteljahresergebnisse der Inlandsproduktsberechnung, 1991 bis 1994, Früheres Bundesgebiet, Statistisches Bundesamt Wiesbaden, September 1997, p. 23.

${ }^{8}$ We succeeded to collect nearly all data on trade flows among countries of our sample. For example, we have only 23 missing or zero-trade observations for 1997. Therefore, the possible bias of truncated data is not important in this case. See for example Baldwin (1994) and Head and Mayer (2000) for discussion of gravity models estimated in truncated data samples.
} 
and strongly significant. The coefficients estimated for GDPs of the importing and exporting country are not significantly different from each other. This is a general property of the gravity model - the home and foreign economies have the same effects on bilateral trade flows. Although there is some variation in the coefficient estimates over time, the values for individual years are never significantly different from each other at conventional levels. Countries sharing the same border, and English-speaking countries trade more intensely with each other. After transformation of logs to levels, trade between two neighboring countries exceeds the normal level (trade as predicted by GDP and distance between the two countries) of trade nearly 1.5 times, and trade between English-speaking countries exceeds the normal level nearly three times. The effects of common border and English language appear also very stable over time.

Our primary interest concerns the trade patterns among the former constituent Republics of the Soviet Union, Yugoslavia and Czechoslovakia. The intensity of trade relations among these countries is reflected in the coefficient estimates for the respective dummies (Table 2). In addition, Figure 1 depicts the evolution of these coefficients graphically, along with two-standard-error bounds.

\section{Insert Figure 1 about here.}

The results are strikingly similar for the former Soviet Union, the Baltics and the former Czechoslovakia, with trade flows exceeding the normal level approximately 41-43 times ${ }^{9}$ during the first year for which we have data (1991 for Czechoslovakia, and 1992 for the Baltics and Belarus-Russia-Ukraine). These results indicate a much higher home bias that what is typically found in the literature (cf. McCallum, 1995, Helliwell, 1997, Wei 1996, and Nitsch, 1998).

Clearly, the intensity of trade within the former strongly centralized federations in Eastern Europe cannot be justified only by greater efficiency of intra-federation trade. In part, it reflected the relative closed nature of these formerly socialist economies and the fact that during the early 1990s, their trade with Western Europe was still not very liberalized

\footnotetext{
${ }^{9}$ The coefficient estimates for the first year are between 3.71 and 3.77. The corresponding multiplicative factors are $\exp (3.71)=40.9$ and $\exp (3.77)=43.4$.
} 
(East-West trade relations are discussed in greater detail below). In the case of the Baltics and Belarus-Russia-Ukraine, their relative remoteness from the major Western European markets probably plays a role too. In contrast to the former Soviet Union and Czechoslovakia, the trade between Slovenia and Croatia exceeded the normal level only 24 $(\exp (3.184)=24.1$.$) times in 1990 .{ }^{10}$ This extent of home bias, while still high, is more similar to that observed for market economies.

The intensity of trade relations fell sharply after disintegration. To some extent, the reduction in trade intensity was natural because of the extremely high inward orientation and closed nature of these countries' economies as discussed above. Most likely, the home bias would have fallen even without the break-up. Indeed, in the case of the former Czechoslovakia, the trade intensity fell already during 1992, i.e. before the break-up, to 32 times the normal level. Nevertheless, the timing and the steepness of the decline suggest that disintegration was an important factor.

While the decline in trade intensity occurred immediately after the break-up in the cases of Slovenia-Croatia, the Baltics, and the former Czechoslovakia,the decline of trade intensity among Belarus, Russia and Ukraine started in the earnest only in 1995. This delay probably reflects the continued existence of a common economic area, and in particular the continued use of the Soviet (Russian) ruble in the CIS for an intermediate period after the break-up in 1991.

The case of the former Czechoslovakia is particularly interesting. The intensity of trade between the Czech and Slovak Republics fell sharply and uninterruptedly despite attempts by the successor countries to sustain a relatively high degree of integration. The Czech and Slovak Republics retained a customs union, a temporary clearing-account payment mechanism (until 1997), and free movement of labor (see Dedek, 1996). Yet, the intensity of trade relations dropped sharply, especially during 1993 and 1994, i.e. the first two years after the division of Czechoslovakia. Bilateral trade, which still exceeded the normal level 32 times in 1992, fell to 11 times the normal level in 1994. Then, the decline slowed down but

\footnotetext{
${ }^{10}$ Note that we do not have trade between Slovenia and Croatia in 1991. This is indicated in Figure 1 on the xaxis, as well as by a dotted line before 1992 .
} 
continued, falling eventually to about seven times the normal level in 1998. Although the trade intensity as measured by the estimated coefficient on trade flows between the Czech Republic and Slovakia declined continuously, the actual volume of trade recovered slightly between 1993 and 1998.

Unlike in the former Czechoslovakia, the trade intensity among the Baltic countries and Slovenia-Croatia picked up temporarily after the initial sharp decline of trade in the wake of the break-up, before declining further eventually. For the Baltics, the trade intensity fell to 12 times the normal level in 1994, rising again to 23 in 1997 and finally falling to 13 times the normal level in 1998. The trade intensity between Slovenia and Croatia deteriorated to three times the normal level by 1994. After a slight recovery in 1995 and 1996 (with the home bias rising to four), it fell again to approximately two times the normal level in 1998 .

The renewed deterioration of bilateral trade among the Baltics and between Slovenia and Croatia may be due to the inclusion of Estonia and Slovenia in the first wave of EU accession negotiations. This political decision increased the attractiveness of these two countries for trade and investment flows from the EU as well as third countries, thus diverting trade from the traditional trade partners. The negative opinion of the European Commission regarding non-standard trade relations of potential new members with the 'leftouts' may have played a role too. Similar factors may be behind the continued fall of bilateral trade between the Czech and Slovak Republics.

In contrast, the trade relations among Belarus, Russia and Ukraine followed a Ushaped pattern. The disintegration of the Soviet Union brought about a sharp deterioration of trade, reaching the bottom at eight times the normal level in 1997. However, 1998 brought a recovery to more than 30 times the normal level. Besides potential political reasons, such as the Russian-Belarussian attempts at re-integration, this may be a consequence of the Russian crisis. The crisis caused a breakdown of trade between the FSU and the developed countries. This was reflected in the rise of relative importance of trade within the FSU area. In addition, this increase in trade intensity may be driven by greater prevalence of re-exports from Belarus and Ukraine to Russia while reporting them as bilateral trade. 
In summary, the empirical evidence suggests that disintegration processes in Eastern Europe brought about substantial declines in trade relations between the former constituent Republics. Nevertheless, the trade intensity continues to be relatively high, even when controlling for common border and membership in free trade areas such as CEFTA. This is in line with the findings of Fidrmuc (1999) who notes that Western European countries with common history and/or the same or similar languages also have more intensive bilateral trade relations. For example, he reports that Austrian trade with Germany is approximately twice higher than the normal level, trade between Sweden and Norway, and the UK and Ireland exceeds the normal level 2.5 times, and trade between Belgium and the Netherlands is triple the normal level. Accordingly, given the obvious cultural, social and linguistic links among the countries included in our analysis, it is reasonable to expect that, absent further exogenous shocks, their bilateral trade relations will continue to be substantialy more intensive than relations with respect to third countries.

\section{German Reunification}

In this section, we consider an episode presenting the counterpart of disintegration-the reunification of Germany. Available trade statistics indicate that the reunific ation brought about a sharp increase of trade between former West Germany and the GDR, with the bulk of this increase occurring already before the political reunification. ${ }^{11}$ According to West German data, West German exports to former East Germany nearly tripled between 1988 and 1990. However, export growth slowed down between 1992 and 1994. The growth of West German imports from former East Germany was not nearly as dramatic as the growth of exports. In 1994, the volume of West German exports exceeded imports from the East approximately five times.

Because data pertaining the pre-reunification period are not comparable with the later data, ${ }^{12}$ we estimate the intensity of trade between the two German entities starting with 1991. Moreover, we were unable to obtain data on East-West trade after 1994. For these

\footnotetext{
${ }^{11}$ After the fall of the Berlin Wall in November 1989, the two Germanies formed an economic and monetary union on July 1, 1990. The political unification formally materialized on October 3, 1990.

12 The pre-unification data measure only goods exports whereas the later data also include services, see Haschke (1993).
} 
reasons, our analysis of intra-German post-reunification trade pertains only to the period between 1991 and 1994. As the previous discussion suggests, the evolution of West German exports and imports differs considerably. Therefore, we estimate separate coefficients for both directions of trade flows. The distance between West and East Germany is estimated as the distance between Berlin and Frankfurt (530 km). Using different distance would change the coefficient estimates correspondingly, but not the dynamics of estimated trade intensities. GDP estimates for former East Germany are taken from Ragnitz et al. (2000). According to Ragnitz et al. (2000) and Von Hagen and Strauch (2000), transfers from West German States amounted to between $40 \%$ and $50 \%$ of East German GDP during the analyzed period. To account for the transfers, we reduced the estimates of East German GDP accordingly. So adjusted GDP better serves as a proxy for the supply of goods to explain West German imports from this region.

According to our estimates (Figure 2), West German exports were approximately six times greater than the normal level in 1991. The subsequent years brought a slight decline, to five times the normal level in 1994. This trade intensity corresponds to the lower bound of available estimates of home bias in developed countries. As such, it is in fact lower than the estimate of German home bias (ten) reported by Nitsch (1998). The slight decline in intensity of exports may reflect the gradual reduction of budgetary transfers and infrastructure investment in former East Germany during the analyzed period. On the other hand, the intensity of East German exports to West Germany increased between 1991 and 1994, albeit remaining at a much lower level: $71 \%$ above the normal level in 1991 and increasing to $77 \%$ by 1994 . Hence, our results suggest that the German reunification brought about a substantial increase in the intensity of West German exports to former East Germany, whereas the intensity of flows in the opposite direction increased much more modestly. Apparently, much of the increase in exports was fueled by government transfers and infrastructure investments, rather than East German demand. As transfers and investments continue to fall in the future, so will the intensity of West German exports.

\section{Insert Figure 2 about here.}




\section{Formal Preferential Trade Areas}

The results presented in the previous section suggest that the former constituent Republics of demised federations continue $\mathfrak{b}$ have strong trade relations, although their intensity is much less than before the break-up. In the present section, we discuss the trade effects of formal preferential trade areas-the EU, EFTA, CEFTA and the Europe Agreements - and compare them with trade patterns within the former federations.

Trade among the five Central European countries that eventually formed the CEFTA (Central European Free Trade Agreement) was initially on a downward trajectory following the dissolution of the CMEA in 1991—see Figure 3. ${ }^{13}$ During 1992 and 1993, trade within CEFTA (encompassing initially the Czech Republic, Hungary, Poland and Slovakia and subsequently extended to include also Slovenia ${ }^{14}$ ) roughly corresponded to their incomes and distances (after controlling for the special trade relations between the Czech and Slovak Republic). Afterwards, trade relations gradually intensified, until reaching approximately twice the normal level of trade by 1997. According to the full sample, intra-CEFTA trade deteriorated again in 1998, to some $40 \%$ above the normal level, it remains to be seen whether this is change in trend will be sustained.

\section{Insert Figure 3 about here.}

Trade between Western and Eastern European countries was affected by many trade restrictions during the cold war period, and, unsurprisingly, was far below the normal level at the beginning of the 1990s. According to the restricted sample, the trade of the 12 member states of the European Community with the group of countries, with which it later concluded the Europe Agreements ${ }^{15}$, was about $40 \%$ below the normal level. The trade of Austria, Finland and Sweden with these countries was one-third below the normal level. According to the full sample, the trade intensity was even lower. Trade liberalization following the collapse of communist regimes boosted trade among the former cold-war

\footnotetext{
${ }^{13}$ Cheikbossian and Maurel (1998) show that the collapse of trade among the CMEA countries started already in the mid 1980s.

${ }^{14}$ Bulgaria and Romania recently joined the CEFTA too, however, in our analysis we only consider the trade flows among the four founding members and Slovenia

${ }^{15}$ Bulgaria, Czech Republic, Estonia, Hungary, Latvia, Lithuania, Poland, Romania, Slovakia and Slovenia.
} 
adversaries. The results based on the restricted sample indicate that trade between the EC12 and the associated countries reached the normal level by 1993. The EFTA3 countries (Austria, Finland and Sweden) liberalized their trade with the associated countries even faster. However, according to the full sample, which also includes the newly created countries, the trade relations of both the EC12 and EFTA3 with the associated countries did not reach the normal level until 1995.

\section{Insert Figure 4 about here.}

Formation of free trade areas in Western Europe had a positive although not very strong effect on trade flows - see Figure 5. In fact, the trade effect of Western European preferentialtrade areas falls short even of that of the CEFTA. Trade between two EC12 countries exceeds trade between two comparable non-EU countries by one half on average. Despite deepening integration during the 1990s, in particular introduction of the Single Market in 1992, the effect of the EU on trade intensity remained stagnant. In fact, it appears that intra-union trade intensity actually declined slightly over time. The coefficient estimate fell from 0.417 in 1990 to 0.355 in 1998 , although this decline is not statistically significant. ${ }^{16}$ The accession of Austria, Finland and Sweden in 1995 had little if any effect on the trade intensity between the original EU members and the new members. The effect of the EFTA on trade intensity is even smaller. Although the coefficient estimate is positive, it is not significant at all except for 1992-93. At its peak in 1993, trade intensity within EFTA exceeded the normal level by less than $30 \%$. In contrast, the trade relations of Austria, Finland and Sweden (EFTA3) with the EU were much more intense than the trade relations within EFTA. By 1990, the EFTA3 countries traded by about one-fourth more with the EC countries than with the other countries in our sample. The main upward shift in the trade intensity occurred already in 1992 and preceded both the formation of the European Economic Area and the entry of these three countries to the European Union.

\section{Insert Figure 5 about here.}

\footnotetext{
${ }^{16}$ This disappointing result is in line with the findings of Soloaga and Winter (1999), and others.
} 


\section{Sensitivity Analysis—Augmented Gravity Models}

In this Section, we subject our results to robustness checks by replicating the analysis for alternative specifications of the gravity model augmented by additional explanatory variables. Besides assessing robustness, some of these variables, especially those related to exchange-rate variability, can provide additional insights on factors explaining the sharp decline of the 'home bias' in the wake of disintegration.

The first extension of the gravity equation is a measure of remoteness. Deardoff (1995) argues that not only the distance between two countries determines the bilateral trade volume, but also their geographic position relative to other countries. Given bilateral distance, two countries trade more if they are both more distant to other potential trade partners. Following this argument, Wei (1996) augments the gravity model by the following measures of the exporter's and importer's overall remoteness, $R_{X}$ and $R_{M}$, respectively,

$$
R_{k}=\sum_{i} w_{i} D_{i k}, k=X, M,
$$

which is defined as a weighted average of distances to other countries, with the weight $w_{i}$ is the share of country $i$ in world output. ${ }^{17}$ As the countries under focus in this paper are located on the periphery (at least relative to the countries included in our sample), the former members of disintegrated countries should on average trade more intensively than similar, but more centrally located, countries.

Another extension of the gravity model is to reveal exchange rate effects (including formation of a currency union) on trade flows. Rose (2000) estimates that countries with a common currency tade over three times as much with other as countries with different currencies. This result is reexamined and confirmed by Rose and Frankel (2000).

Unfortunately, we cannot separately estimate the effects of currency separation and political disintegration because the two events typically unfolded nearly parallel to each other. Nevertheless, the increased exchange rate volatility between the affected countries

\footnotetext{
${ }^{17}$ We also tried an alternative measure of remoteness used by Wolf (1997) defined as ratio of the bilateral distance to an average of $R_{X}$ and $R_{M}, R_{I J}=D_{I J} / 0.5\left(R_{X}+R_{M}\right)$. However, this remoteness measure was less robust than those defined by (2).
} 
should bring about a decline in bilateral trade. Following Frankel (2000), we therefore augment the gravity equation with a measure volatility (standard deviation) of monthly bilateral exchange rate (first differences of $\operatorname{logs}$ ), $s_{i p}$ in respective years. Furthermore, we include also the importer's and exporter's average exchange rate volatility towards their trade partners as Wei (1996), $s_{i}=\sum_{j}^{n} s_{i j} / n$.

However, we should keep in mind that the effects of exchange rate volatility are generally less robust that those of currency unions. According to Frankel (2000), a reduction of exchange rate volatility is of magnitude less important than the effects of a currency union, but these effects are statistically significant. Wei (1996) even fails to find significant and theory consistent effects of exchange rate volatility on trade flows at all.

Thus, our augmented version of the gravity model, see (1), includes five additional variables: remoteness of exporter and importers, $R_{X}$ and $R_{M}$, respectively, bilateral exchange rate volatility, $s_{i j}$, and the average exchange rate volatilities of both trade partners, $s_{X}$ and $s_{M}$, respectively,

$$
M=\beta_{1}+\beta_{2} Y_{M}+\beta_{3} Y_{X}+\beta_{4} d+\beta_{5} s_{i j}+\sum_{j=X, M} \beta_{j} s_{j}+\sum_{i=X, M} \beta_{i} \log \left(R_{i}\right)+\sum_{k} \beta_{k} D_{k}+\varepsilon .
$$

The results of the augmented gravity model are reported in Table 4. The inclusion of additional variables does not change our results dramatically. Remoteness of exporter and importer has the correct (positive) sign. In general, our results do not show any stable effect of bilateral exchange rate variability on trade flows, although we do find negative and significant effects of average exchange-rate volatility of both exporter and importer for several years.

\section{Insert Table 4 about here.}

In fact, the effect of bilateral exchange-rate volatility turns out significant and positive in four years (1992, 1995, 1996 and 1998) whereas it is estimated as significantly negative only in one year (1991). This can be due to the inclusion of additional Central and Eastern European countries, with high trade growth and high exchange-rate fluctuations. Indeed, the bilateral exchange rate has the correct (negative) sign when we estimate (3) with the 
restricted sample at the beginning of the analyzed period, although the estimated coefficient is again not robust in the subsequent years. ${ }^{18}$

Importantly, the inclusion of additional variables has little effect on our estimates of home bias for the former federations in Eastern Europe (and especially so for SloveniaCroatia and the former Czechoslovakia). For most of the analyzed period, the estimates of home bias differs little whether estimated with the traditional or augmented gravity model. Hence, the relative remoteness of these countries and the exchange-rate volatility after the break-up do note explain the size of this bias. Given the overall low robustness of these additional variables, the traditional specification of the gravity model seems to be more appropriate for this kind of analysis.

Further possible sophistications of the gravity model concern the estimation technique. So far, we estimated gravity models in a series of independent cross sections for individual years. Baldwin (1994), Mátyás (1997) and Cheng and Wall (1999) argue that instead panel-data techniques are more appropriate. In particular, Cheng and Wall (1999) argue that, in cross-section analysis, the gravity model yields biased estimates, which tend to overestimate trade between low-trade countries and to underestimate it between high trade countries.

Therefore, we estimate the gravity model in three alternative specifications (see Table 5): (a) pooled cross section, (b) fixed effects model with time effects for individual years $\left(\tau_{t}\right)$, and (c) fixed effect model with country effects $\left(\phi_{i j}\right)$.

$$
\begin{gathered}
M=\beta_{1}+\beta_{2} Y_{M}+\beta_{3} Y_{X}+\beta_{4} d+\beta_{5} s_{i j}+\sum_{j=X, M} \beta_{j} s_{j}+\sum_{i=X, M} \beta_{i} \log \left(R_{i}\right)+\sum_{k} \beta_{k} D_{k}+\varepsilon(4 \mathrm{a}) \\
M=\sum_{t=1990}^{1998} \tau_{t}+\beta_{2} Y_{M}+\beta_{3} Y_{X}+\beta_{4} d+\beta_{5} s_{i j}+\sum_{j=X, M} \beta_{j} s_{j}+\sum_{i=X, M} \beta_{i} \log \left(R_{i}\right)+\sum_{k} \beta_{k} D_{k}+\varepsilon \text { (4b) } \\
M=\sum_{i} \sum_{j} \phi_{i j}+\beta_{2} Y_{M}+\beta_{3} Y_{X}+\beta_{5} s_{i j}+\sum_{j=X, M} \beta_{j} s_{j}+\sum_{k} \beta_{k} D_{k}+\varepsilon
\end{gathered}
$$

Following Cheng and Wall (1999), we formulate fixed effects for each of approximately 1300 pairs of trade partners and for both directions of trade flows, i.e.

\footnotetext{
${ }^{18}$ These results are available from the authors on request.
} 
$\phi_{i j} \neq \phi_{i j}$ The set of fixed country and time effects replaces the constant in the equation. We measure the effects of disintegration by including a set of dummy variables for selected groups of countries in each available year. This set is multicollinear with the fixed country effects, therefore, we drop one fixed effect for each group of countries created from former multinational federations. The fixed country effects reflect all factors, which are constant for a given pair of countries. Therefore, we have to drop distance, participation in various free trade agreements, and measures of remoteness in the third specification. Time effects (not reported in the Table) in general do not seem important for explanation of trade between 1990 and 1998.

\section{Insert Table 5 about here.}

Indeed, the gravity models estimated for panel data perform slightly better than crosssection estimates. In particular, the average volatility of exchange rates of importing and exporting country has the correct sign (negative) and is highly significant in the regression with country effects. In contrast, volatility of the bilateral exchange rate still has the wrong sign (and is significant). Most importantly, the fixed effect estimation of gravity models confirm our conclusions regarding home bias in the former federations. The main difference is that the home bias estimated with fixed country effects for the former Czechoslovakia and Slovenia-Croatia appears higher than the estimates obtained in cross section. Nevertheless, the evolution of the home bias is essentially the same. In all countries, trade intensity declined dramatically after disintegration.

\section{Conclusions}

Our objective in this paper was to investigate the impact of disintegration on trade. Unlike the impact of integration, the economic consequences of disintegration have been little explored in the literature. We study three recent disintegration episodes in Europe- the break-ups of the Soviet Union, Yugoslavia and Czechoslovakia between 1991 and 1993. Using the gravity model of trade, we assess the evolution of trade relations among the former constituent Republics of these federations in the wake of disintegration. We find evidence of a strong home bias in the former federations: around the time of disintegration, trade between the constituent parts of Czechoslovakia, Soviet Union (represented here by 
Belarus, Russia and Ukraine) and the Baltic countries was approximately 43 times greater than trade with third countries (controlling for GDP and distance). The home bias was lower in Slovenia and Croatia, with their bilateral trade exceeding normal trade only 24 times in 1990. Disintegration was followed by a sharp deterioration of this home bias. Nevertheless, traditional relations die hard, and, by 1998, trade within the former federations exceeded normal trade twice for Slovenia-Croatia, seven times for the former Czechoslovakia, 13 times for the Baltics, and 30 times for Belarus-Russia-Ukraine.

As the evidence from German reunification suggests, integration (or reintegration in this specific case) is followed by an increase in bilateral trade. However, the home bias estimated for trade between West Germany and the former GDR is dwarfed by the results for the former federations in Eastern Europe and even falls short of the home bias estimated for West Germany by Nitsch (1998). Indeed, the data indicate that the intensity of West German exports to the former GDR declined gradually between 1991 and 1994. On the other hand, the increase of East German exports has been much more modest.

In comparison to the formal preferentialtrade areas in Eastern and Western Europe, trade relations among the former constituent Republics of demised federations appear very strong. The difference is particularly pronounced with respect to the intra-EU trade-we found that EU membership on average increases bilateral trade only 1.5 times. Trade intensity in the former federations continues to be high despite greater open and hidden barriers to trade among the successor countries, transaction costs, exchange rate uncertainty and political instability. Hence, the legacy of common past and traditional relations have very strong effects on international trade, apparently much stronger that the effect of formal trade liberalization.

These results suggest that although disintegration is associated with sharp deterioration of bilateral trade intensity, the relations between former constituent parts of a federation retain some of their specific nature for several years after splitting up. The outside economic and political environment seems to matter as well. The Czech and Slovak Republics, which have better access to major Western European markets, experienced a deeper collapse of bilateral trade han the Baltics or Belarus, Russia and Ukraine, despite generally lower barriers to trade in the former Czechoslovakia. The prospects of an early EU membership 
for the Czech Republic, Slovenia and Estonia may have contributed to the further deterioration $f$ trade with their traditional partners in the late 1990s. In contrast, trade intensity among Belarus, Russia and Ukraine actually increased in 1998, possibly as a consequence of the Russian crises, and efforts towards re-unification between Russia and Belarus. Hence, while disintegration matters, the overall context is important as well.

Our findings are broadly consistent with earlier findings on currency unions. In particular, Rose (2000) shows that a common currency increases bilateral trade flows approximately three times. Indeed, we found a decline of bilateral trade intensity by about this factor in the first years of the existence of the new independent states. However, we cannot separate the effect of currency separation from the effect of political disintegration as both effects occurred simultaneously in the countries under scrutiny. However, we do not find a significant effect of the volatility of exchange rates on bilateral trade within our data set.

\section{References}

Baldwin, Richard E. (1994), Towards an Integrated Europe, CEPR, London.

Bayoumi, Tamim, and Eichengreen, Barry (1995), Is Regionalism Simply a Diversion? Evidence from the Evolution of the EC and EFTA, CEPR Discussion Paper No. 1294.

Cheikbossian, Guillaume and Mathilde Maurel (1998), "The New Geography of East European Trade," Kyklos 51 (1), pp. 45-71.

Cheng, I-Hui and Howard J. Wall (1999), Controlling for Heterogeneity in Gravity Models of Trade, Federal Reserve Bank of St. Luis, Working Paper No. 99-01A.

Deardorff, Allan V. (1995), Determinants of Bilateral Trade: Does Gravity Work in a Neoclassical World?, NBER Working Paper No. 5377.

Dedek, Oldrich, Ed. (1996), The Break-up of Czechoslovakia: An In-depth Economic Analysis. Avebury, UK: Aldershot.

De Ménil, Georges and Maurel, Mathilde (1994), "Breaking up a Customs Union: The Case of the Austro-Hungarian Empire in 1919," Weltwirtschaftliches Archiv; 130 (3), 553-575. 
Djankov, Simeon and Caroline Freund (2000), Disintegration, CEPR Discussion Paper No. 2545 .

Eichengreen, Barry, and Douglas A. Irwin (1996), The Role of History in Bilateral Trade Flows, CEPR Discussion Paper No. 5565.

Evenett, S. J., and W. Keller (1998), On the Theories Explaining the Success of the Gravity Equation, NBER Working Paper No. 6529.

Fidrmuc, Jarko (1999), “Trade Diversion in 'Left-Outs' in Eastward Enlargement of European Union, The Case of Slovakia," Europe-Asia Studies 51 (4), 633-645.

Frankel, Jeffrey A and Andrew K. Rose (2000), Estimating the Effects of Currency Unions on Trade and Output, NBER Working Paper No. 7857.

Haschke, Ingrid (1993), "Der innerdeutsche Handel im Strukturwandel," Konjunkturbericht Nr. 5-6, Institut für Wirtschaftsforschung, Halle, 13-19.

Head, K. and T. Mayer (2000), "Non-Europe: The Magnitude and Causes of Market Fragmentation in the EU," Weltwirtschaftliches Archiv 136 (2), 284-314.

Helliwell, John F. (1997), National Borders, Trade and Migration, NBER Working Paper No. 6027.

Helpman, E. and P. R. Krugman (1985), Market Structure and Foreign Trade: Increasing Returns, Imperfect Competition, and the International Economy, MIT Press, Cambridge.

Holzmann, R. and K. Zukowska-Gagelmann (1996), "Exportchancen und Importschocks: Eine Untersuchung zur Asymetrie der Handelsanpassung der OECD-Länder im Gefolge der Marktöffnung in Mittel und Osteuropa," in Holzmann, R. and R. Neck (Eds.), Ostöffnung: Wirtschaftliche Folgen für Österreich, Manzsche VerlagsUniversitätsbuchhandlung, Wien.

Linder, S. (1961), An Essay on Trade and Transformation, Almqvist and Wiksells, Uppsala.

Linnemann, Hans (1966), An Econometric Study of International Trade Flows, Amsterdam.

Mátyás, L. (1997), "Proper Econometric Specification of the Gravity Model," World Economy 20 (3), 363-368. 
McCallum, John (1995), "National Borders Matter: Canada-U.S. Regional Trade Patterns," American Economic Review 85 (3), 615-623.

Mencinger, Joze (1997), "Slovenia: The Economic Situation,” in Heuberger, V., Riegler, H. and H. Vidovic (Eds.), At the Crossroads: Disaster or Normalization? The Yugoslav Successor States in the 1990s, Peter Lang Verlag, Wien, 79-90.

Nitsch, Volker (1998), National Borders and International Trade: Evidence from the European Union, Humbolt University Berlin, mimeo.

Obstfeld, Maurice and Kenneth Rogoff (2000), The Six Major Puzzles in International Macroeconomics: Is There a Common Cause?, NBER Working Paper No. 7777.

Ragnitz, Joachim; Dreger, Christian; Komar, Walter and Gerald Müller (2000), Simulationsrechnungen $z u$ den Auswirkungen einer Kürzung von Transferleistungen für die neuen Bundesländer, Institut für Wirtschaftsforschung, Halle.

Rose, Andrew K. (2000), “One Money, One Market: Estimating the Effect of Common Currencies on Trade," Economic Policy: A European Forum, April 2000, 7-45.

Smarzynska, Beata K. (1999), "Does Relative Location Matter for Bilateral Trade Flows? An Extension of the Gravity Model," The World Bank, mimeo.

Soloaga, Isidro and L. Alan Winters (1999), Regionalism in the Nineties: What Effect on Trade?, CEPR Discussion Paper No. 2183, London.

Stiblar, Franjo (1996), "Potencialni pomen trgov ex-Jugoslavije za Slovenijo," Gospodarska Gibanja No. 267, 23-43.

Von Hagen, Jürgen, and Rolf R. Strauch (2000), East Germany: Transition with Unification-Experiments and Experiences. CEPR Discussion Paper No. 2386.

Wei, Shang-Jin (1996), Intra-national Versus International Trade: How Stubborn Are Nations in Global Integration?, NBER Working Paper No. 5531.

Wolf (1997), Patterns of Intra- and Inter-State Trade, NBER Working Paper No. 5939. WIIW (1999), Countries in Transition 1999, The Vienna Institute for International Economic Studies, Vienna. 


\section{Figure 1: Disintegration in Eastern Europe, Full Sample}
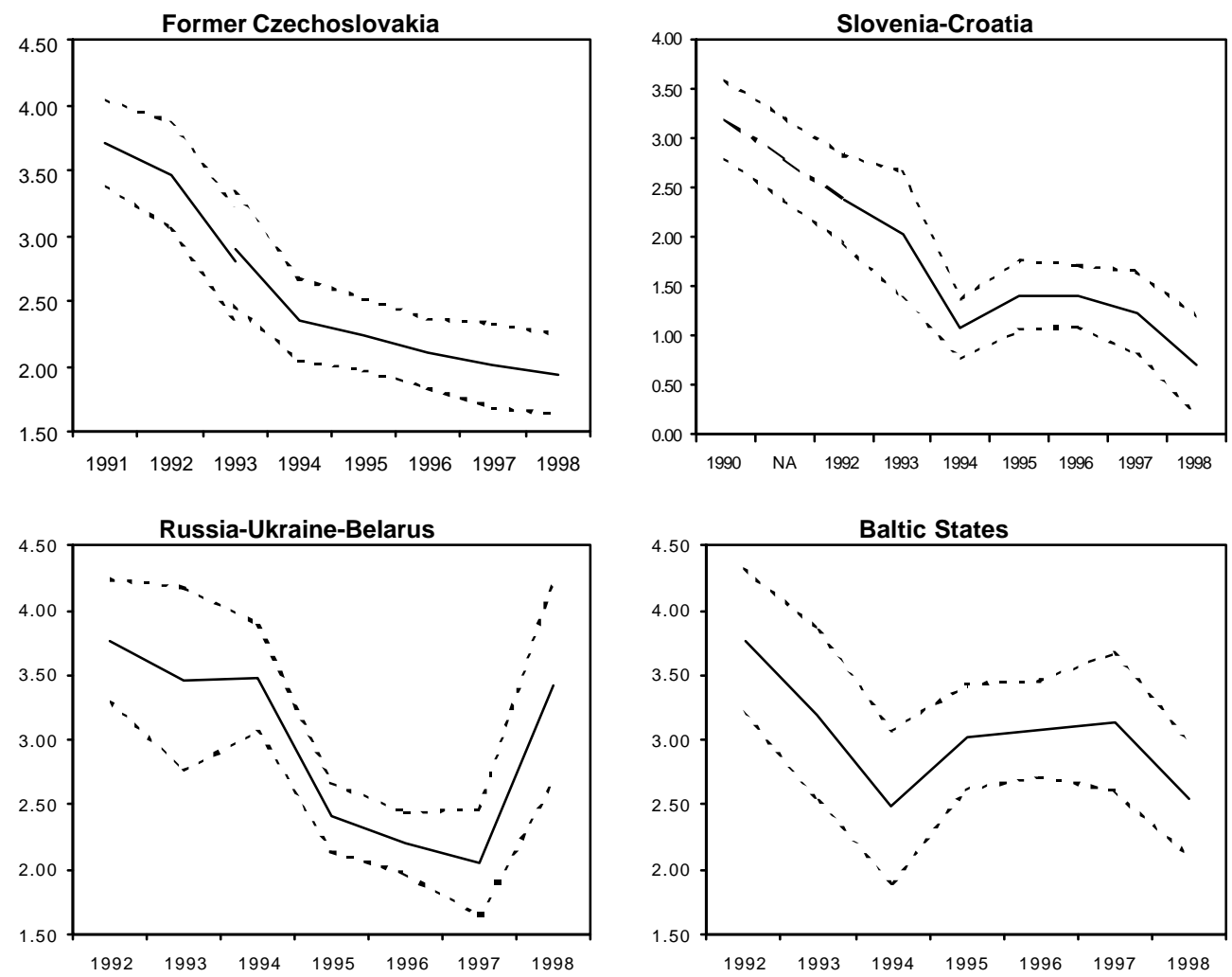

Note: We use estimates for trade flows between the Czech Republic and Slovakia according to delivery statistics of large enterprises in Slovakia (1991-1993), which are not fully comparable to later custom statistics (1993-1997) causing a discontinuity in our estimates in 1993. Trade flows between Slovenia and Croatia in 1990 are according to Mencinger (1998) and WIIW (1999), while trade data on 1991 are not available.

Figure 2: German Reunification, Restricted Sample
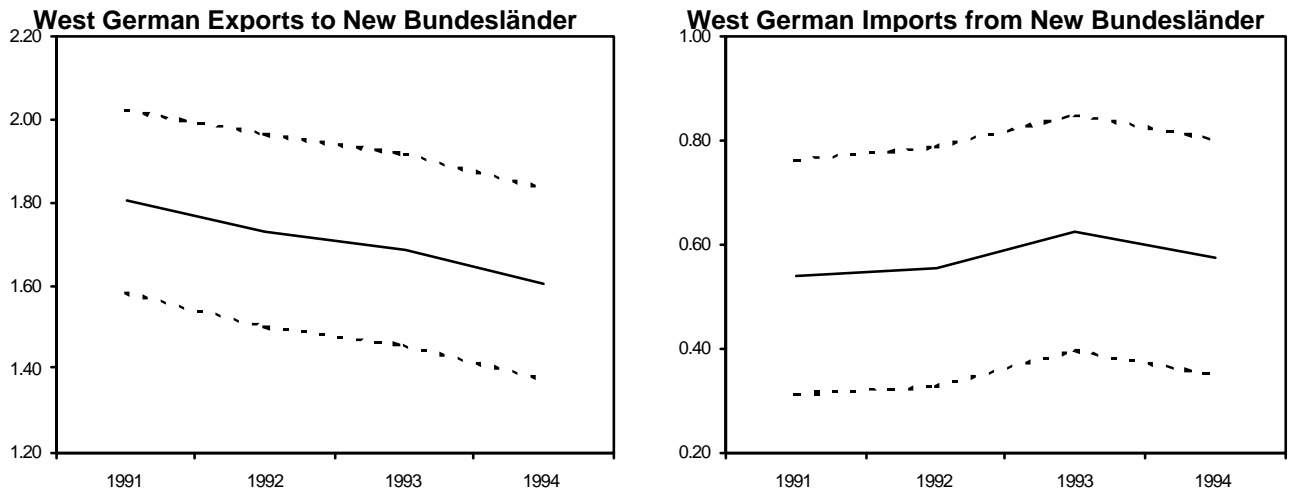
Figure 3: Trade Liberalization in Eastern Europe

\section{A: Restricted Sample*}

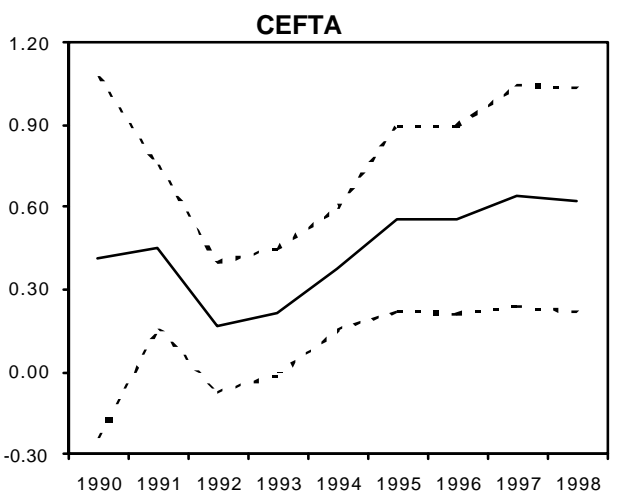

B: Full Sample

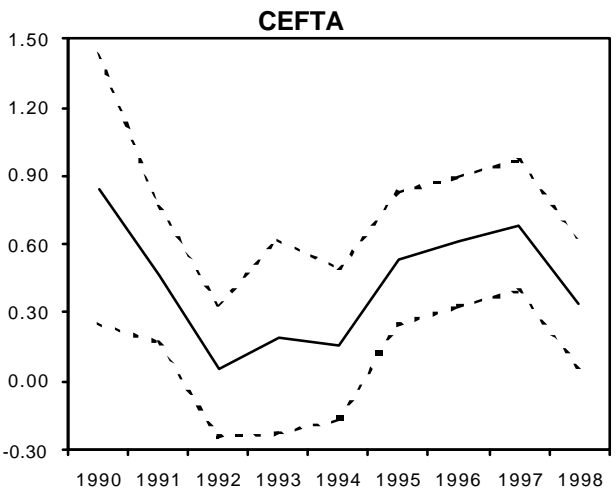

Note: * The restricted sample only contains bilateral trade flows that are available during the whole period 1990 1998.

Figure 4: Trade Relations between East and West A: Restricted Sample
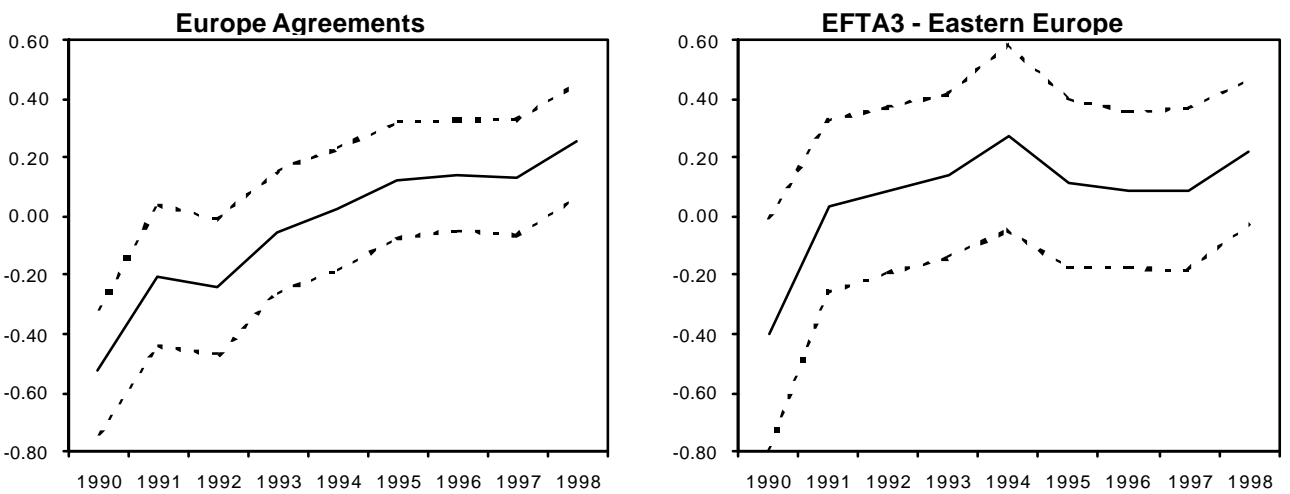

\section{B: Full Sample}
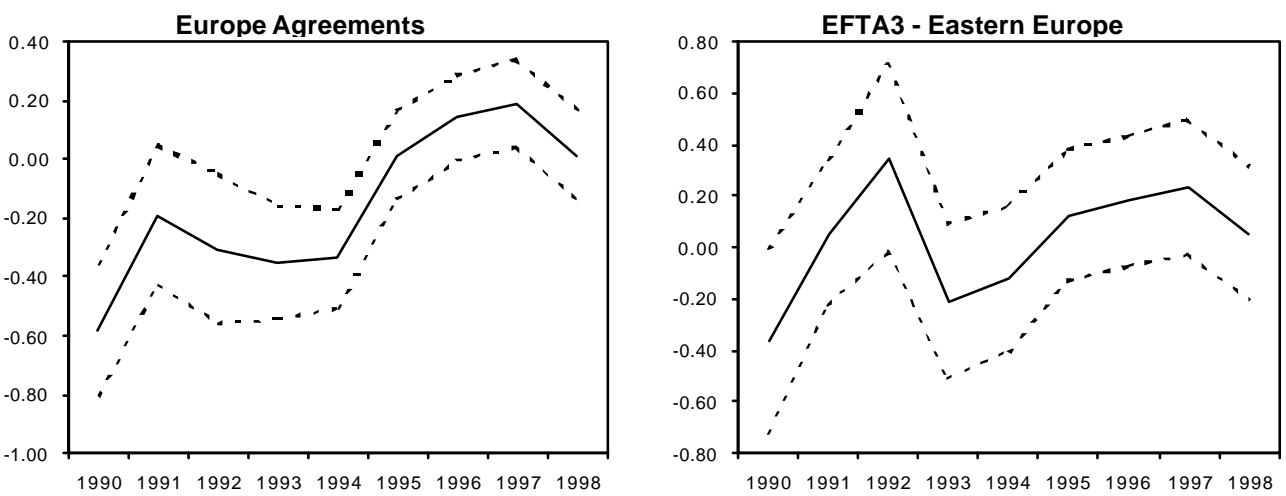

Note: ${ }^{*}$ The restricted sample only contains bilateral trade flows that are available during the whole period 19901998. 
Figure 5: Free Trade Areas in Western Europe, Restricted Sample*
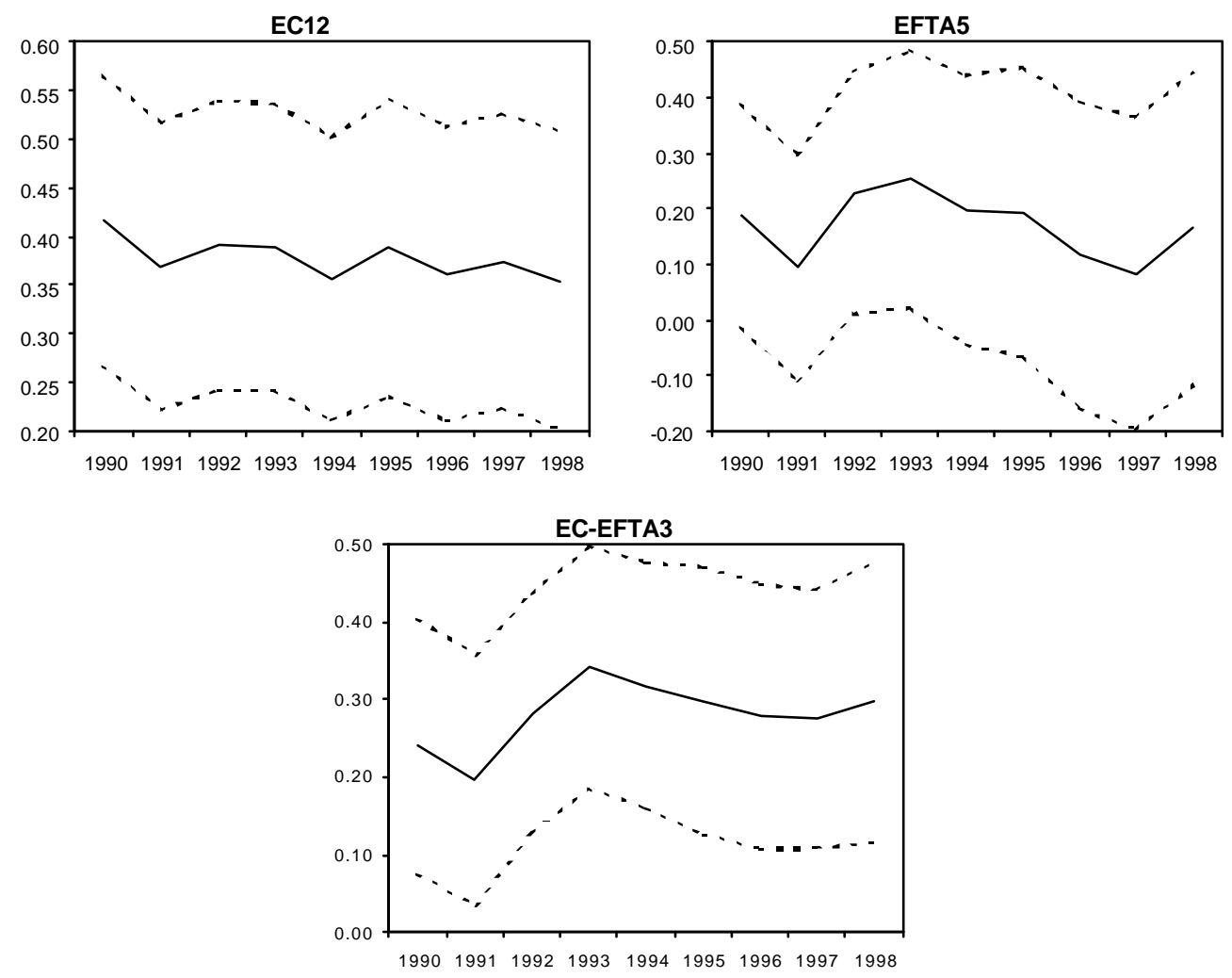

Note: ${ }^{*}$ The restricted sample only contains bilateral trade flows that are available during the whole period 19901998. 
Table 1 Gravity Mode I of Trade Flows, Restricted Sample

\begin{tabular}{|c|c|c|c|c|c|c|c|c|c|}
\hline & 1990 & 1991 & 1992 & 1993 & 1994 & 1995 & 1996 & 1997 & 1998 \\
\hline No. of observations & 630 & 630 & 630 & 630 & 630 & 630 & 630 & 630 & 630 \\
\hline Adjusted $\mathrm{R}^{2}$ & 0.8698 & 0.8853 & 0.8358 & 0.8029 & 0.8361 & 0.8479 & 0.8478 & 0.8407 & 0.8161 \\
\hline \multirow[t]{2}{*}{ Constant } & 3.346 & 3.659 & 3.796 & 3.765 & 3.519 & 3.285 & 3.480 & 3.604 & 3.552 \\
\hline & $(8.742)$ & $(9.540)$ & $(10.251)$ & $(10.358)$ & $(9.962)$ & $(9.128)$ & $(10.121)$ & $(10.519)$ & $(10.242)$ \\
\hline \multirow[t]{2}{*}{ GDP of importing country } & 0.875 & 0.839 & 0.838 & 0.838 & 0.850 & 0.868 & 0.861 & 0.857 & 0.845 \\
\hline & $(36.485)$ & $(35.237)$ & $(36.879)$ & (36.946) & $(36.663)$ & $(37.394)$ & (39.104) & (37.823) & (35.882) \\
\hline \multirow[t]{2}{*}{ GDP of exporting country } & 0.913 & 0.894 & 0.909 & 0.925 & 0.911 & 0.922 & 0.921 & 0.909 & 0.902 \\
\hline & $(40.054)$ & $(44.008)$ & (43.995) & $(45.415)$ & $(45.092)$ & $(42.083)$ & $(44.140)$ & $(44.257)$ & $(40.754)$ \\
\hline \multirow[t]{2}{*}{ Distance } & -0.866 & -0.872 & -0.884 & -0.900 & -0.881 & -0.876 & -0.888 & -0.875 & -0.868 \\
\hline & $(-21.313)$ & $(-21.950)$ & $(-22.333)$ & $(-22.616)$ & $(-22.308)$ & $(-21.557)$ & $(-22.887)$ & $(-22.214)$ & $(-21.796)$ \\
\hline \multirow[t]{2}{*}{ Dummy: Common border } & 0.406 & 0.445 & 0.427 & 0.398 & 0.421 & 0.385 & 0.389 & 0.397 & 0.386 \\
\hline & (3.617) & $(3.606)$ & $(3.257)$ & $(3.084)$ & $(3.241)$ & $(3.185)$ & $(3.359)$ & (3.589) & $(3.332)$ \\
\hline \multirow[t]{2}{*}{ Dummy: English speaking countries } & 1.136 & 1.109 & 1.105 & 1.174 & 1.180 & 1.251 & 1.154 & 1.130 & 1.276 \\
\hline & $(6.178)$ & $(5.953)$ & $(5.469)$ & $(6.122)$ & $(6.262)$ & $(6.946)$ & $(6.397)$ & $(6.065)$ & $(7.001)$ \\
\hline \multirow[t]{2}{*}{ Dummy: EC12 } & 0.417 & 0.370 & 0.391 & 0.389 & 0.357 & 0.388 & 0.361 & 0.375 & 0.355 \\
\hline & $(5.459)$ & $(4.892)$ & (5.134) & (5.134) & (4.779) & $(4.961)$ & $(4.669)$ & $(4.836)$ & $(4.517)$ \\
\hline \multirow[t]{2}{*}{ Dummy: CEFTA } & 0.418 & 0.451 & 0.164 & 0.217 & 0.378 & 0.557 & 0.554 & 0.641 & 0.626 \\
\hline & $(1.249)$ & $(2.960)$ & $(1.353)$ & $(1.825)$ & (3.257) & $(3.213)$ & $(3.159)$ & (3.094) & $(2.997)$ \\
\hline \multirow[t]{2}{*}{ Dummy: Europe Agreements } & -0.528 & -0.201 & -0.240 & -0.052 & 0.025 & 0.124 & 0.140 & 0.132 & 0.259 \\
\hline & $(-4.832)$ & $(-1.626)$ & $(-2.027)$ & $(-0.484)$ & $(0.237)$ & $(1.220)$ & $(1.466)$ & $(1.310)$ & $(2.632)$ \\
\hline \multirow[t]{2}{*}{ Dummy: EFTA } & 0.189 & 0.094 & 0.228 & 0.253 & 0.198 & 0.195 & 0.116 & 0.083 & 0.165 \\
\hline & $(1.845)$ & $(0.900)$ & $(2.041)$ & (2.138) & $(1.592)$ & (1.463) & $(0.823)$ & $(0.578)$ & $(1.147)$ \\
\hline \multirow[t]{2}{*}{ Dummy: EC12- EFTA3 } & 0.240 & 0.196 & 0.281 & 0.342 & 0.319 & 0.299 & 0.279 & 0.275 & 0.297 \\
\hline & $(2.836)$ & $(2.374)$ & $(3.550)$ & $(4.267)$ & $(3.924)$ & $(3.379)$ & $(3.180)$ & (3.224) & $(3.201)$ \\
\hline \multirow{2}{*}{$\begin{array}{l}\text { Dummy: EFTA3-Associated } \\
\text { countries }\end{array}$} & -0.400 & 0.034 & 0.091 & 0.137 & 0.271 & 0.112 & 0.090 & 0.092 & 0.219 \\
\hline & $(-1.975)$ & $(0.225)$ & $(0.628)$ & $(0.959)$ & $(1.671)$ & $(0.759)$ & $(0.659)$ & $(0.652)$ & $(1.749)$ \\
\hline
\end{tabular}

Notes: T-statistics (heteroscedasticity robust) in parentheses. Estimated on bilateral trade flows among OECD countries (excl. Mexico and Korea), and Central and Eastern European countries. CEFTA includes the Czech Republic, Hungary, Poland, Slovakia and Slovenia. EC12 refers to the 12 countries who were the members of the European Community until 1995. EFTA includes EFTA3 (Austria, Finland, and Sweden ) and Norway and Switzerland. Associated countries are Bulgaria, Czech Republic, Estonia, Hungary, Latvia, Lithuania, Poland, Romania, Slovakia and Slovenia. 
Table 2 Gravity Model of Trade Flows, Full Sample

\begin{tabular}{|c|c|c|c|c|c|c|c|c|c|}
\hline & 1990 & 1991 & 1992 & 1993 & 1994 & 1995 & 1996 & 1997 & 1998 \\
\hline No. of observations & 670 & 643 & 836 & 1140 & 1219 & 1248 & 1247 & 1238 & 1247 \\
\hline Adjusted $\mathrm{R}^{2}$ & 0.8698 & 0.8853 & 0.8358 & 0.8029 & 0.8361 & 0.8479 & 0.8478 & 0.8407 & 0.8161 \\
\hline \multirow[t]{2}{*}{ Constant } & 3.372 & 3.663 & 4.426 & 4.691 & 4.786 & 4.206 & 4.136 & 4.311 & 4.776 \\
\hline & $(8.400)$ & $(9.613)$ & (10.137) & (13.123) & (15.977) & $(14.610)$ & $(14.887)$ & $(15.281)$ & $(15.036)$ \\
\hline \multirow[t]{2}{*}{ GDP of importing country } & 0.873 & 0.852 & 0.903 & 0.838 & 0.845 & 0.873 & 0.853 & 0.855 & 0.823 \\
\hline & $(35.596)$ & $(36.001)$ & $(38.751)$ & (43.194) & $(47.957)$ & $(51.761)$ & $(50.953)$ & $(51.032)$ & (40.779) \\
\hline \multirow[t]{2}{*}{ GDP of exporting country } & 0.924 & 0.899 & 0.865 & 0.872 & 0.860 & 0.939 & 0.959 & 0.958 & 0.935 \\
\hline & $(40.777)$ & $(44.504)$ & $(36.782)$ & $(44.072)$ & $(48.944)$ & $(55.925)$ & $(57.897)$ & $(54.998)$ & $(45.399)$ \\
\hline \multirow[t]{2}{*}{ Distance } & -0.877 & -0.886 & -0.976 & -0.988 & -1.007 & -1.024 & -1.016 & -1.025 & -1.040 \\
\hline & $(-21.689)$ & $(-21.920)$ & $(-20.744)$ & $(-24.005)$ & $(-26.899)$ & $(-28.098)$ & $(-28.010)$ & $(-27.599)$ & $(-23.753)$ \\
\hline \multirow[t]{2}{*}{ Dummy: Common border } & 0.317 & 0.454 & 0.608 & 0.537 & 0.760 & 0.664 & 0.631 & 0.595 & 0.670 \\
\hline & $(2.552)$ & (3.706) & $(3.575)$ & $(2.251)$ & $(5.691)$ & $(5.567)$ & $(5.712)$ & $(5.364)$ & (5.009) \\
\hline \multirow{2}{*}{$\begin{array}{l}\text { Dummy: English speaking } \\
\text { countries }\end{array}$} & 1.169 & 1.128 & 1.179 & 1.342 & 1.360 & 1.536 & 1.479 & 1.493 & 1.535 \\
\hline & $(6.381)$ & $(6.048)$ & $(5.828)$ & (7.333) & (7.557) & (8.713) & (8.273) & (7.980) & (8.498) \\
\hline \multirow[t]{2}{*}{ Dummy: EC12 } & 0.437 & 0.364 & 0.288 & 0.377 & 0.289 & 0.396 & 0.447 & 0.471 & 0.309 \\
\hline & $(5.650)$ & $(4.821)$ & $(3.498)$ & $(4.570)$ & $(3.852)$ & $(5.070)$ & $(5.815)$ & $(6.143)$ & (3.730) \\
\hline \multirow[t]{2}{*}{ Dummy: CEFTA } & 0.842 & 0.466 & 0.050 & 0.195 & 0.163 & 0.537 & 0.613 & 0.681 & 0.344 \\
\hline & $(2.783)$ & $(3.051)$ & $(0.334)$ & $(0.901)$ & $(0.965)$ & $(3.627)$ & $(4.227)$ & $(4.653)$ & $(2.387)$ \\
\hline \multirow[t]{2}{*}{ Dummy: Europe Agreements } & -0.580 & -0.190 & -0.303 & -0.351 & -0.337 & 0.015 & 0.141 & 0.193 & 0.014 \\
\hline & $(-5.114)$ & $(-1.564)$ & $(-2.329)$ & $(-3.573)$ & $(-3.875)$ & $(0.191)$ & (1.889) & $(2.524)$ & $(0.177)$ \\
\hline \multirow[t]{2}{*}{ Dummy: EFTA } & 0.230 & 0.089 & 0.070 & 0.158 & -0.022 & 0.099 & 0.120 & 0.110 & -0.011 \\
\hline & $(2.100)$ & $(0.876)$ & $(0.637)$ & (1.104) & $(-0.209)$ & $(0.881)$ & $(0.985)$ & $(0.880)$ & $(-0.087)$ \\
\hline \multirow[t]{2}{*}{ Dummy: EC12- EFTA3 } & 0.245 & 0.190 & 0.233 & 0.344 & 0.294 & 0.375 & 0.409 & 0.411 & 0.306 \\
\hline & $(2.896)$ & $(2.310)$ & $(2.771)$ & $(4.448)$ & (3.684) & $(4.230)$ & (4.714) & $(4.803)$ & (3.174) \\
\hline \multirow{2}{*}{$\begin{array}{l}\text { Dummy: EFTA3-Associated } \\
\text { countries }\end{array}$} & -0.364 & 0.057 & 0.350 & -0.207 & -0.119 & 0.127 & 0.181 & 0.237 & 0.055 \\
\hline & $(-1.982)$ & $(0.392)$ & (1.879) & $(-1.344)$ & $(-0.828)$ & $(0.966)$ & (1.393) & $(1.766)$ & $(0.415)$ \\
\hline \multirow[t]{2}{*}{ Dummy: Baltic States } & & & 3.766 & 3.188 & 2.485 & 3.024 & 3.088 & 3.142 & 2.556 \\
\hline & & & (13.130) & $(9.454)$ & $(8.241)$ & $(14.533)$ & $(16.165)$ & $(11.585)$ & (11.202) \\
\hline \multirow{2}{*}{$\begin{array}{l}\text { Dummy: Russia-Belarus- } \\
\text { Ukraine }\end{array}$} & & & 3.771 & 3.467 & 3.480 & 2.407 & 2.207 & 2.057 & 3.427 \\
\hline & & & $(15.740)$ & $(9.596)$ & $(16.561)$ & $(18.024)$ & $(18.347)$ & $(9.807)$ & $(8.663)$ \\
\hline \multirow[t]{2}{*}{ Dummy: Slovenia-Croatia } & & & 2.382 & 2.021 & 1.075 & 1.413 & 1.404 & 1.231 & 0.708 \\
\hline & & & $(10.535)$ & $(6.124)$ & $(7.004)$ & (7.823) & (8.872) & $(5.695)$ & $(2.810)$ \\
\hline \multirow[t]{2}{*}{ Dummy: Former Czechoslovakia } & & & & 2.905 & 2.359 & 2.245 & 2.099 & 2.006 & 1.939 \\
\hline & & & & (12.968) & $(14.550)$ & (15.885) & (15.472) & (12.224) & $(12.350)$ \\
\hline
\end{tabular}

Notes: See Table 1. 
Table 3 Gravity Model of Trade Flows, Using Alternative Estimates of Trade Flows between Selected Pairs of Countries

\begin{tabular}{|c|c|c|c|c|c|c|c|c|}
\hline & $1990^{\mathrm{SLO}}$ & $1991^{\mathrm{CS}}$ & $1992^{\mathrm{CS}}$ & $1993^{\mathrm{CS}}$ & $1991^{\mathrm{GE}}$ & $1992^{\mathrm{GE}}$ & $1993^{\mathrm{GE}}$ & $1994^{\mathrm{GE}}$ \\
\hline No. of observations & 672 & 645 & 838 & 1140 & 632 & 632 & 632 & 632 \\
\hline Adjusted $\mathrm{R}^{2}$ & 0.8699 & 0.8855 & 0.8360 & 0.8028 & 0.8825 & 0.8805 & 0.8803 & 0.8786 \\
\hline \multirow[t]{2}{*}{ Constant } & 3.372 & 3.663 & 4.426 & 4.691 & 3.659 & 3.796 & 3.765 & 3.519 \\
\hline & $(8.400)$ & $(9.613)$ & $(10.137)$ & $(13.123)$ & $(9.540)$ & $(10.251)$ & $(10.358)$ & $(9.962)$ \\
\hline \multirow[t]{2}{*}{ GDP of importing country } & 0.873 & 0.852 & 0.903 & 0.838 & 0.839 & 0.838 & 0.838 & 0.850 \\
\hline & $(35.596)$ & $(36.005)$ & $(38.752)$ & $(43.195)$ & $(35.237)$ & (36.879) & (36.947) & (36.663) \\
\hline \multirow[t]{2}{*}{ GDP of exporting country } & 0.924 & 0.899 & 0.865 & 0.872 & 0.894 & 0.909 & 0.925 & 0.911 \\
\hline & $(40.780)$ & $(44.510)$ & $(36.787)$ & $(44.071)$ & (44.008) & $(43.995)$ & $(45.415)$ & $(45.092)$ \\
\hline \multirow[t]{2}{*}{ Distance } & -0.877 & -0.886 & -0.976 & -0.988 & -0.872 & -0.884 & -0.900 & -0.881 \\
\hline & $(-21.689)$ & $(-21.920)$ & $(-20.744)$ & $(-24.005)$ & $(-21.950)$ & $(-22.333)$ & $(-22.616)$ & $(-22.308)$ \\
\hline \multirow[t]{2}{*}{ Dummy: Common border } & 0.317 & 0.454 & 0.608 & 0.537 & 0.445 & 0.427 & 0.398 & 0.421 \\
\hline & $(2.552)$ & (3.706) & $(3.575)$ & (2.251) & (3.606) & $(3.257)$ & (3.084) & $(3.241)$ \\
\hline Dummy: English speaking & 1.169 & 1.128 & 1.179 & 1.342 & 1.109 & 1.105 & 1.174 & 1.180 \\
\hline Countries & $(6.381)$ & $(6.048)$ & $(5.828)$ & (7.333) & $(5.953)$ & $(5.469)$ & $(6.122)$ & $(6.262)$ \\
\hline \multirow[t]{2}{*}{ Dummy: EC12 } & 0.437 & 0.364 & 0.288 & 0.377 & 0.370 & 0.391 & 0.389 & 0.357 \\
\hline & $(5.650)$ & $(4.821)$ & (3.498) & $(4.570)$ & (4.892) & (5.134) & (5.134) & (4.779) \\
\hline \multirow[t]{2}{*}{ Dummy: CEFTA } & 0.842 & 0.466 & 0.050 & 0.195 & 0.451 & 0.164 & 0.217 & 0.378 \\
\hline & $(2.783)$ & $(3.051)$ & $(0.334)$ & $(0.901)$ & $(2.960)$ & $(1.353)$ & $(1.825)$ & $(3.257)$ \\
\hline \multirow[t]{2}{*}{ Dummy: Europe Agreements } & -0.580 & -0.190 & -0.303 & -0.351 & -0.201 & -0.240 & -0.052 & 0.025 \\
\hline & $(-5.114)$ & $(-1.564)$ & $(-2.329)$ & $(-3.573)$ & $(-1.626)$ & $(-2.027)$ & $(-0.484)$ & $(0.237)$ \\
\hline \multirow[t]{2}{*}{ Dummy: EFTA } & 0.230 & 0.089 & 0.070 & 0.158 & 0.094 & 0.228 & 0.253 & 0.198 \\
\hline & (2.100) & $(0.876)$ & $(0.637)$ & (1.104) & $(0.900)$ & (2.041) & (2.138) & $(1.592)$ \\
\hline \multirow[t]{2}{*}{ Dummy: EC12- EFTA3 } & 0.245 & 0.190 & 0.233 & 0.344 & 0.196 & 0.281 & 0.342 & 0.319 \\
\hline & $(2.896)$ & $(2.310)$ & $(2.771)$ & (4.448) & $(2.374)$ & $(3.550)$ & $(4.267)$ & (3.924) \\
\hline Dummy: EFT A 3-Associated & -0.364 & 0.057 & 0.350 & -0.207 & 0.034 & 0.091 & 0.137 & 0.271 \\
\hline Countries & $(-1.982)$ & $(0.392)$ & $(1.879)$ & $(-1.344)$ & $(0.225)$ & $(0.628)$ & $(0.959)$ & $(1.671)$ \\
\hline \multirow[t]{2}{*}{ Dummy: Baltic States } & & & 3.767 & 3.188 & & & & \\
\hline & & & $(13.130)$ & (9.454) & & & & \\
\hline Dummy: Russia-Belarus- & & & 3.771 & 3.467 & & & & \\
\hline Ukraine & & & $(15.741)$ & $(9.596)$ & & & & \\
\hline \multirow[t]{2}{*}{ Dummy: Slovenia-Croatia } & 3.184 & & 2.382 & 2.021 & & & & \\
\hline & $(15.746)$ & & $(10.535)$ & $(6.124)$ & & & & \\
\hline \multirow[t]{2}{*}{ Dummy: Former Czechoslovakia } & & 3.713 & 3.466 & 2.798 & & & & \\
\hline & & $(22.106)$ & $(16.628)$ & $(12.568)$ & & & & \\
\hline Dummy: West German Exports to & & & & & 1.801 & 1.731 & 1.685 & 1.603 \\
\hline former East Germany & & & & & $(16.039)$ & $(14.610)$ & $(14.344)$ & $(13.608)$ \\
\hline Dummy: West German Imports from & & & & & 0.536 & 0.555 & 0.621 & 0.574 \\
\hline former East Germany & & & & & $(4.645)$ & $(4.710)$ & $(5.355)$ & (4.934) \\
\hline
\end{tabular}

Notes: See Table 1. ${ }^{\text {SLO }}$ Estimates of trade flows between Slovenia and Croatia according to Mencinger (1998) and WIIW (1999). ${ }^{\text {CS }}$ Enterprise delivery statistics as estimates of trade flows between the Czech Republic and Slovakia for 1991-1993. ${ }^{\text {GE }}$ Trade flows (including services) between West Germany and former East Germany accor ding to German Statistical Office. 
Table 4 Augmented Gravity Model of Trade Flows, Full Sample

\begin{tabular}{|c|c|c|c|c|c|c|c|c|c|}
\hline & 1990 & 1991 & 1992 & 1993 & 1994 & 1995 & 1996 & 1997 & 1998 \\
\hline No. of observations & 619 & 643 & 641 & 1140 & 1219 & 1248 & 1247 & 1238 & 1247 \\
\hline Adjusted $\mathrm{R}^{2}$ & 0.8735 & 0.8902 & 0.8851 & 0.8076 & 0.8414 & 0.8505 & 0.8514 & 0.8420 & 0.8296 \\
\hline \multirow[t]{2}{*}{ Constant } & -9.316 & -9.096 & -9.179 & -6.527 & -3.452 & -2.618 & -2.135 & -2.447 & -1.945 \\
\hline & $(-3.335)$ & $(-3.080)$ & $(-3.059)$ & $(-2.243)$ & $(-1.171)$ & $(-0.891)$ & $(-0.770)$ & $(-0.896)$ & $(-0.686)$ \\
\hline \multirow[t]{2}{*}{ GDP of importing country } & 0.926 & 0.898 & 0.897 & 0.896 & 0.887 & 0.889 & 0.879 & 0.874 & 0.869 \\
\hline & $(35.056)$ & $(35.308)$ & $(37.964)$ & (41.257) & (47.113) & $(49.260)$ & $(48.327)$ & (46.396) & $(44.382)$ \\
\hline \multirow[t]{2}{*}{ GDP of exporting country } & 0.937 & 0.958 & 0.960 & 0.928 & 0.904 & 0.955 & 0.993 & 0.989 & 0.993 \\
\hline & $(37.734)$ & $(40.921)$ & $(45.392)$ & $(44.013)$ & (47.694) & $(52.977)$ & $(54.431)$ & $(49.454)$ & (45.503) \\
\hline \multirow[t]{2}{*}{ Distance } & -0.989 & -1.043 & -1.094 & -1.080 & -1.100 & -1.118 & -1.118 & -1.109 & -1.128 \\
\hline & $(-17.841)$ & $(-16.903)$ & $(-18.769)$ & $(-22.595)$ & $(-24.946)$ & $(-25.564)$ & $(-26.365)$ & $(-26.374)$ & $(-24.533)$ \\
\hline \multirow[t]{2}{*}{ Remoteness of importing country } & 0.867 & 0.741 & 0.838 & 0.620 & 0.480 & 0.462 & 0.395 & 0.399 & 0.165 \\
\hline & $(4.094)$ & (3.168) & $(3.525)$ & $(2.593)$ & $(1.985)$ & $(1.938)$ & $(1.783)$ & (1.799) & $(0.699)$ \\
\hline \multirow[t]{2}{*}{ Remoteness of exporting country } & 0.614 & 0.737 & 0.794 & 0.604 & 0.474 & 0.399 & 0.436 & 0.430 & 0.617 \\
\hline & (3.166) & $(3.529)$ & (3.756) & $(3.040)$ & $(2.416)$ & $(1.965)$ & $(2.326)$ & $(2.314)$ & (3.047) \\
\hline \multirow[t]{2}{*}{ Volatility of bilateral exch. rate } & -0.081 & -0.041 & 0.110 & -0.031 & 0.047 & 0.146 & 0.311 & 0.037 & 0.087 \\
\hline & $(-0.890)$ & $(-1.725)$ & (2.204) & $(-0.669)$ & $(0.851)$ & $(3.681)$ & $(3.276)$ & $(1.318)$ & $(2.021)$ \\
\hline \multirow{2}{*}{$\begin{array}{l}\text { Average exchange rate volatility } \\
\text { of importing country }\end{array}$} & 0.076 & 0.043 & -0.097 & 0.057 & -0.011 & -0.106 & -0.296 & -0.038 & -0.052 \\
\hline & $(0.797)$ & $(1.744)$ & $(-1.593)$ & (1.134) & $(-0.185)$ & $(-1.943)$ & $(-2.997)$ & $(-1.334)$ & $(-1.080)$ \\
\hline \multirow{2}{*}{$\begin{array}{l}\text { Average exchange rate volatility } \\
\text { of exporting country }\end{array}$} & 0.063 & 0.047 & -0.102 & 0.054 & -0.015 & -0.116 & -0.276 & -0.027 & -0.047 \\
\hline & $(0.655)$ & $(1.876)$ & $(-1.890)$ & $(1.083)$ & $(-0.251)$ & $(-1.953)$ & $(-2.763)$ & $(-0.929)$ & $(-1.003)$ \\
\hline \multirow[t]{2}{*}{ Dummy: Common border } & 0.194 & 0.241 & 0.270 & 0.410 & 0.666 & 0.585 & 0.583 & 0.533 & 0.549 \\
\hline & $(1.628)$ & $(1.922)$ & $(1.948)$ & (1.669) & (4.893) & (4.932) & (5.085) & $(4.620)$ & $(4.495)$ \\
\hline \multirow{2}{*}{$\begin{array}{l}\text { Dummy: English speaking } \\
\text { countries }\end{array}$} & 0.863 & 0.888 & 1.051 & 1.185 & 1.329 & 1.540 & 1.496 & 1.427 & 1.559 \\
\hline & $(5.800)$ & $(5.522)$ & $(5.850)$ & (7.169) & (7.792) & $(9.201)$ & (8.539) & (8.163) & (8.312) \\
\hline \multirow[t]{2}{*}{ Dummy: EC12 } & 0.388 & 0.347 & 0.385 & 0.407 & 0.370 & 0.430 & 0.488 & 0.484 & 0.459 \\
\hline & (4.802) & (4.474) & (4.814) & (4.776) & (4.675) & (5.374) & $(6.067)$ & (6.076) & (5.210) \\
\hline \multirow[t]{2}{*}{ Dummy:CEFTA } & 1.011 & 0.548 & 0.194 & 0.461 & 0.374 & 0.562 & 0.666 & 0.719 & 0.562 \\
\hline & (3.215) & $(3.700)$ & (1.598) & (2.052) & (2.233) & (3.839) & $(4.461)$ & (4.907) & (4.102) \\
\hline \multirow[t]{2}{*}{ Dummy: Europe Agreements } & -0.368 & -0.053 & -0.257 & -0.163 & -0.186 & 0.085 & 0.160 & 0.209 & 0.222 \\
\hline & $(-2.646)$ & $(-0.426)$ & $(-2.167)$ & $(-1.626)$ & $(-2.206)$ & (1.122) & (2.203) & $(2.761)$ & (2.789) \\
\hline \multirow[t]{2}{*}{ Dummy: EFTA } & 0.199 & 0.129 & 0.223 & 0.255 & 0.085 & 0.175 & 0.130 & 0.121 & 0.171 \\
\hline & (1.755) & (1.180) & (1.937) & (1.700) & $(0.780)$ & (1.618) & (1.045) & $(0.932)$ & (1.308) \\
\hline \multirow[t]{2}{*}{ Dummy: EC12- EFTA3 } & 0.224 & 0.217 & 0.305 & 0.418 & 0.386 & 0.442 & 0.447 & 0.443 & 0.472 \\
\hline & $(2.477)$ & $(2.483)$ & $(3.671)$ & (4.989) & $(4.640)$ & $(4.842)$ & (5.087) & $(4.961)$ & $(4.752)$ \\
\hline Dummy: EFTA3-Associated & -0.164 & 0.156 & 0.087 & -0.044 & -0.014 & 0.143 & 0.133 & 0.212 & 0.254 \\
\hline Countries & $(-0.797)$ & $(1.036)$ & $(0.592)$ & $(-0.276)$ & $(-0.100)$ & $(1.095)$ & $(1.024)$ & $(1.546)$ & $(1.887)$ \\
\hline
\end{tabular}


Table 4: Continued

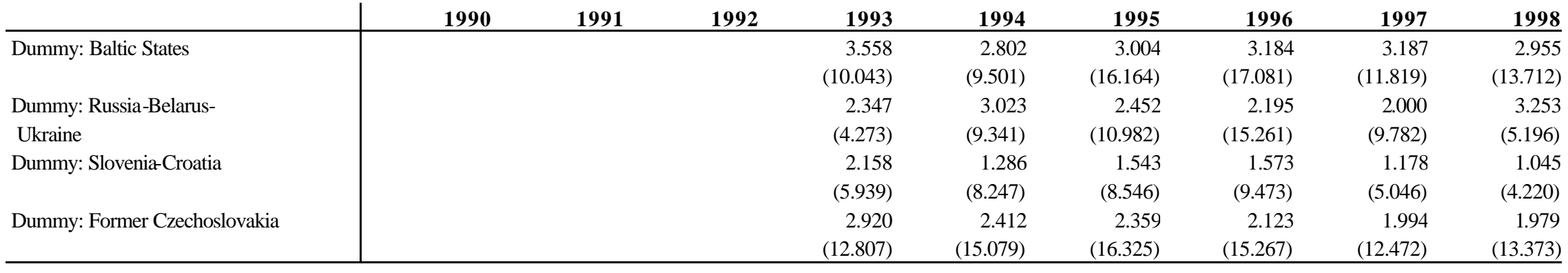

Notes: See Table 1. 
Table 5 Augmented Gravity Model of Trade Flows, Panel Data

\begin{tabular}{|c|c|c|c|}
\hline & Pooled Data $^{a}$ & Time Effects $^{\text {b }}$ & Country effects ${ }^{c}$ \\
\hline No. of observations & 9242 & 9242 & 9242 \\
\hline Adjusted $\mathrm{R}^{2}$ & 0.8448 & 0.8455 & 0.9703 \\
\hline \multirow[t]{2}{*}{ GDP of importing country } & 0.884 & 0.881 & 0.873 \\
\hline & (123.633) & (123.659) & $(27.269)$ \\
\hline \multirow[t]{2}{*}{ GDP of exporting country } & 0.956 & 0.953 & 0.362 \\
\hline & (131.065) & (131.372) & $(11.730)$ \\
\hline \multirow[t]{2}{*}{ Distance } & -1.092 & -1.098 & \\
\hline & $(-68.733)$ & $(-68.307)$ & \\
\hline \multirow[t]{2}{*}{ Dummy: Common border } & 0.490 & 0.498 & \\
\hline & $(9.705)$ & $(9.700)$ & \\
\hline \multirow{2}{*}{$\begin{array}{l}\text { Dummy: English speaking } \\
\text { countries }\end{array}$} & 1.259 & 1.272 & \\
\hline & $(22.764)$ & $(22.322)$ & \\
\hline \multirow[t]{2}{*}{ Dummy: EC12 } & 0.406 & 0.397 & \\
\hline & (15.148) & $(14.741)$ & \\
\hline \multirow[t]{2}{*}{ Dummy: CEFTA } & 0.554 & 0.544 & \\
\hline & (9.284) & $(9.031)$ & \\
\hline \multirow[t]{2}{*}{ Dummy: Europe Agreements } & -0.057 & -0.068 & \\
\hline & $(-1.881)$ & $(-2.233)$ & \\
\hline \multirow[t]{2}{*}{ Dummy: EFTA } & 0.139 & 0.120 & \\
\hline & $(3.406)$ & $(2.959)$ & \\
\hline \multirow[t]{2}{*}{ Dummy: EC12- EFTA3 } & 0.367 & 0.357 & \\
\hline & (12.457) & $(12.122)$ & \\
\hline \multirow{2}{*}{$\begin{array}{l}\text { Dummy: EFTA3-Associated } \\
\text { Countries }\end{array}$} & 0.045 & 0.029 & \\
\hline & $(0.902)$ & $(0.582)$ & \\
\hline \multirow[t]{2}{*}{ Remoteness of importing country } & 0.524 & 0.523 & \\
\hline & $(6.723)$ & $(6.697)$ & \\
\hline \multirow[t]{2}{*}{ Remoteness of exporting country } & 0.549 & 0.549 & \\
\hline & $(8.217)$ & $(8.180)$ & \\
\hline \multirow[t]{2}{*}{ Volatility of bilateral exch. rate } & 0.009 & 0.038 & 0.013 \\
\hline & (1.924) & $(2.309)$ & $(6.353)$ \\
\hline \multirow{2}{*}{$\begin{array}{l}\text { Average exchange rate volatility } \\
\text { of importing country }\end{array}$} & 0.003 & -0.029 & -0.008 \\
\hline & $(0.632)$ & $(-1.616)$ & $(-3.577)$ \\
\hline \multirow{2}{*}{$\begin{array}{l}\text { Average exchange rate volatility } \\
\text { of exporting country }\end{array}$} & 0.007 & -0.025 & -0.012 \\
\hline & $(1.440)$ & $(-1.405)$ & $(-5.059)$ \\
\hline
\end{tabular}


Table 5: Continued

\begin{tabular}{|c|c|c|c|}
\hline & Pooled Data $^{a}$ & Time Effects $^{b}$ & Country effects $^{c}$ \\
\hline \multirow[t]{2}{*}{ Dummy for CSFR, 1993} & 2.756 & 2.724 & 3.793 \\
\hline & $(44.843)$ & $(38.465)$ & (33.028) \\
\hline \multirow[t]{2}{*}{ Dummy for CSFR, 1994} & 2.407 & 2.410 & 3.475 \\
\hline & $(38.251)$ & $(35.291)$ & $(28.081)$ \\
\hline \multirow[t]{2}{*}{ Dummy for CSFR, 1995} & 2.277 & 2.353 & 3.409 \\
\hline & $(33.896)$ & $(32.842)$ & $(25.319)$ \\
\hline \multirow[t]{2}{*}{ Dummy for CSFR, 1996} & 2.142 & 2.189 & 3.322 \\
\hline & (37.074) & $(35.136)$ & $(26.495)$ \\
\hline \multirow[t]{2}{*}{ Dummy for CSFR, 1997} & 2.170 & 2.152 & 3.384 \\
\hline & (19.014) & $(18.458)$ & $(25.262)$ \\
\hline \multirow[t]{2}{*}{ Dummy for CSFR, 1998} & 1.999 & 1.957 & 3.313 \\
\hline & $(17.781)$ & (16.919) & $(22.571)$ \\
\hline \multirow[t]{2}{*}{ Dummy for SLO-HR, 1993} & 2.109 & 2.029 & 3.692 \\
\hline & $(20.953)$ & $(17.954)$ & $(35.447)$ \\
\hline \multirow[t]{2}{*}{ Dummy for SLO-HR, 1994} & 1.511 & 1.495 & 3.131 \\
\hline & $(21.269)$ & $(19.901)$ & $(25.883)$ \\
\hline \multirow[t]{2}{*}{ Dummy for SLO-HR, 1995} & 1.423 & 1.499 & 3.111 \\
\hline & $(10.482)$ & $(10.882)$ & $(29.838)$ \\
\hline \multirow[t]{2}{*}{ Dummy for SLO-HR, 1996} & 1.353 & 1.396 & 3.049 \\
\hline & (11.803) & (11.990) & $(28.386)$ \\
\hline \multirow[t]{2}{*}{ Dummy for SLO-HR, 1997} & 1.197 & 1.140 & 2.962 \\
\hline & $(6.296)$ & $(5.930)$ & $(25.889)$ \\
\hline \multirow[t]{2}{*}{ Dummy for SLO-HR, 1998} & 1.019 & 0.967 & 2.815 \\
\hline & $(4.875)$ & $(4.590)$ & (19.506) \\
\hline \multirow[t]{2}{*}{ Dummy for Baltic States, 1993} & 3.557 & 3.479 & 3.114 \\
\hline & $(17.853)$ & $(17.276)$ & (20.814) \\
\hline \multirow[t]{2}{*}{ Dummy for Baltic States, 1994} & 3.041 & 3.008 & 2.748 \\
\hline & (13.076) & $(12.866)$ & $(17.325)$ \\
\hline \multirow[t]{2}{*}{ Dummy for Baltic States, 1995} & 3.001 & 3.033 & 2.814 \\
\hline & (19.714) & (19.883) & $(17.535)$ \\
\hline \multirow[t]{2}{*}{ Dummy for Baltic States, 1996} & 3.027 & 3.054 & 2.925 \\
\hline & $(20.483)$ & $(20.429)$ & (19.730) \\
\hline \multirow[t]{2}{*}{ Dummy for Baltic States, 1997} & 3.139 & 3.092 & 3.122 \\
\hline & $(13.298)$ & $(13.221)$ & $(18.135)$ \\
\hline \multirow[t]{2}{*}{ Dummy for Baltic States, 1998} & 2.854 & 2.795 & 3.000 \\
\hline & $(15.686)$ & $(15.249)$ & $(12.563)$ \\
\hline \multirow[t]{2}{*}{ Dummy for CIS, 1993} & 3.140 & 3.418 & 2.760 \\
\hline & $(14.136)$ & (12.409) & (11.185) \\
\hline \multirow[t]{2}{*}{ Dummy for CIS, 1994} & 3.626 & 3.715 & 2.956 \\
\hline & $(17.959)$ & $(18.931)$ & (13.871) \\
\hline \multirow[t]{2}{*}{ Dummy for CIS, 1995} & 2.299 & 2.426 & 2.086 \\
\hline & $(27.969)$ & $(26.481)$ & $(7.670)$ \\
\hline \multirow[t]{2}{*}{ Dummy for CIS, 1996} & 2.088 & 2.139 & 1.940 \\
\hline & $(24.845)$ & $(23.957)$ & $(8.023)$ \\
\hline \multirow[t]{2}{*}{ Dummy for CIS, 1997} & 1.952 & 1.939 & 1.934 \\
\hline & (10.634) & (10.749) & $(7.852)$ \\
\hline Dummy for CIS, 1998 & 3.263 & 3.565 & 3.041 \\
\hline & $(9.243)$ & $(8.681)$ & $(9.994)$ \\
\hline
\end{tabular}

Notes: See Table 1. ${ }^{\mathrm{a}}$ constant not reported, ${ }^{\mathrm{b}}$ time effects not reported, ${ }^{\mathrm{c}}$ country effects not reported. 


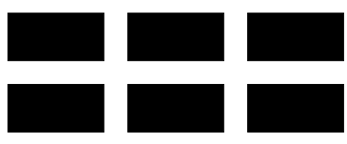

THE WILLIAM DAVIDSON INSTITUTE

AT THE UNIVERSITY OF MICHIGAN BUSINESSSCHOOL

\section{DAVIDSON INSTITUTE WORKING PAPER SERIES}

Working Papers are available at: www.wdi.bus.umich.edu

CURRENT AS OF $12 / 20 / 00$

\begin{tabular}{|c|c|c|}
\hline Publication & Authors & Date \\
\hline No. 353 Disintegration and Trade & Jarko Fidrmuc and Jan Fidrmuc & Nov. 2000 \\
\hline $\begin{array}{l}\text { No. } 352 \text { Social Capital and Entrepreneurial Performance in Russia: A } \\
\text { Panel Study }\end{array}$ & Bat Batjargal & Dec. 2000 \\
\hline $\begin{array}{l}\text { No. 351 Entrepreneurial Versatility, Resources and Firm Performance in } \\
\text { Russia: A Panel Study }\end{array}$ & Bat Batjargal & Dec. 2000 \\
\hline $\begin{array}{l}\text { No. } 350 \text { The Dynamics of Entrepreneurial Networks in a Transitional } \\
\text { Economy: The Case of Russia }\end{array}$ & Bat Batjargal & Dec. 2000 \\
\hline $\begin{array}{l}\text { No. } 349 \text { R\&D and Technology Spillovers via FDI: Innovation and } \\
\text { Absorptive Capacity }\end{array}$ & Yuko Kinoshita & Nov. 2000 \\
\hline $\begin{array}{l}\text { No. } 348 \text { Microeconomic aspects of Economic Growth in Eastern } \\
\text { Europe and the Former Soviet Union, } 1950-2000\end{array}$ & Sergei Guriev and Barry W. Ickes & Nov. 2000 \\
\hline $\begin{array}{l}\text { No. } 347 \text { Effective versus Statutory Taxation: Measuring Effective Tax } \\
\text { Administration in Transition Economies }\end{array}$ & $\begin{array}{l}\text { Mark E. Schaffer and Gerard } \\
\text { Turley }\end{array}$ & Nov. 2000 \\
\hline $\begin{array}{l}\text { No. } 346 \text { Objectives and Constraints of Entrepreneurs: Evidence from } \\
\text { Small and Medium Size Enterprises in Russia and Bulgaria }\end{array}$ & $\begin{array}{l}\text { Francesca Pissarides, Miroslav } \\
\text { Singer and Jan Svejnar }\end{array}$ & Oct. 2000 \\
\hline No. 345 Corruption and Anticorruption in the Czech Republic & $\begin{array}{l}\text { Lubomír Lízal and Evžen } \\
\text { Kočenda }\end{array}$ & Oct. 2000 \\
\hline No. 344 The Effects of Direct Foreign Investment on Domestic Firms & Jozef Konings & Oct. 2000 \\
\hline No. 343 On the Identification of Relative Wage Rigidity Dynamics & Patrick A. Puhani & Oct. 2000 \\
\hline $\begin{array}{l}\text { No. } 342 \text { The Determinants of Foreign Direct Investment in Transition } \\
\text { Economies }\end{array}$ & Alan A. Bevan and Saul Estrin & Oct. 2000 \\
\hline No. 341 The Global Spread of Stock Exchanges, 1980-1998 & Klaus Weber and Gerald F. Davis & Nov. 2000 \\
\hline $\begin{array}{l}\text { No. } 340 \text { The Costs and Benefits of Euro-isation in Central-Eastern } \\
\text { Europe Before or Instead of EMU Membership }\end{array}$ & D. Mario Nuti & Oct. 2000 \\
\hline No. 339 Debt Overhang and Barter in Russia & $\begin{array}{l}\text { Sergei Guriev, Igor Makarov and } \\
\text { Mathilde Maurel }\end{array}$ & Sept. 2000 \\
\hline $\begin{array}{l}\text { No. } 338 \text { Firm Performance and the Political Economy of Corporate } \\
\text { Governance: Survey Evidence for Bulgaria, Hungary, Slovakia and } \\
\text { Slovenia }\end{array}$ & $\begin{array}{l}\text { Patrick Paul Walsh and Ciara } \\
\text { Whela }\end{array}$ & July 2000 \\
\hline No. 337 Investment and Instability & $\begin{array}{l}\text { Nauro F. Campos and Jeffrey B. } \\
\text { Nugent }\end{array}$ & May 2000 \\
\hline $\begin{array}{l}\text { No. } 336 \text { The Evolution of the Insurance Sector in Central and } \\
\text { Eastern Europe and the former Soviet Union }\end{array}$ & Robert B.K. Pye & Aug. 2000 \\
\hline $\begin{array}{l}\text { No. } 335 \text { Institutional Technology and the Chains of Trust: Capital } \\
\text { Markets and Privatization in Russia and the Czech Republic }\end{array}$ & Bruce Kogut and Andrew Spicer & Aug. 2000 \\
\hline No. 334 The Evolution of Market Integration in Russia & $\begin{array}{l}\text { Daniel Berkowitz and David N. } \\
\text { DeJong }\end{array}$ & Aug. 2000 \\
\hline No. 333 Efficiency and Market Share in Hungarian Corporate Sector & László Halpern and Gábor Körösi & July 2000 \\
\hline No. 332 Search-Money-and-Barter Models of Financial Stabilization & $\begin{array}{l}\text { S.I. Boyarchenko and S.Z. } \\
\text { Levendorskii }\end{array}$ & July 2000 \\
\hline $\begin{array}{l}\text { No. } 331 \text { Worker Training in a Restructuring Economy: Evidence from } \\
\text { the Russian Transition }\end{array}$ & $\begin{array}{l}\text { Mark C. Berger, John S. Earle } \\
\text { and Klara Z. Sabirianova }\end{array}$ & Aug. 2000 \\
\hline $\begin{array}{l}\text { No. } 330 \text { Economic Development in Palanpur 1957-1993: A Sort of } \\
\text { Growth }\end{array}$ & Peter Lanjouw & Aug. 2000 \\
\hline $\begin{array}{l}\text { No. } 329 \text { Trust, Organizational Controls, Knowledge Acquisition from } \\
\text { the Foreign Parents, and Performance in Vietnamese International Joint } \\
\text { Ventures }\end{array}$ & $\begin{array}{l}\text { Marjorie A. Lyles, Le Dang } \\
\text { Doanh, and Jeffrey Q. Barden }\end{array}$ & June 2000 \\
\hline
\end{tabular}




\begin{tabular}{|c|c|c|}
\hline $\begin{array}{l}\text { No. } 328 \text { Comparative Advertising in the Global Marketplace: The } \\
\text { Effects of Cultural Orientation on Communication }\end{array}$ & $\begin{array}{l}\text { Zeynep Gürhan-Canli and } \\
\text { Durairaj Maheswaran }\end{array}$ & Aug. 2000 \\
\hline No. 327 Post Privatization Enterprise Restructuring & Morris Bornstein & July 2000 \\
\hline No. 326 Who is Afraid of Political Instability? & $\begin{array}{l}\text { Nauro F. Campos and Jeffrey B. } \\
\text { Nugent }\end{array}$ & July 2000 \\
\hline No. 325 Business Groups, the Financial Market and Modernization & Raja Kali & June 2000 \\
\hline $\begin{array}{l}\text { No. } 324 \text { Restructuring with What Success? A Case Study of Russian } \\
\text { Firms }\end{array}$ & Susan Linz & July 2000 \\
\hline $\begin{array}{l}\text { No. } 323 \text { Priorities and Sequencing in Privatization: Theory and } \\
\text { Evidence from the Czech Republic }\end{array}$ & $\begin{array}{l}\text { Nandini Gupta, John C. Ham and } \\
\text { Jan Svejnar }\end{array}$ & May 2000 \\
\hline $\begin{array}{l}\text { No. } 322 \text { Liquidity, Volatility, and Equity Trading Costs Across } \\
\text { Countries and Over Time }\end{array}$ & $\begin{array}{l}\text { Ian Domowitz, Jack Glen and } \\
\text { Ananth Madhavan }\end{array}$ & Mar. 2000 \\
\hline $\begin{array}{l}\text { No. } 321 \text { Equilibrium Wage Arrears: A Theoretical and Empirical } \\
\text { Analysis of Institutional Lock-In }\end{array}$ & $\begin{array}{l}\text { John S. Earle and Klara Z. } \\
\text { Sabirianova }\end{array}$ & Oct. 2000 \\
\hline No. 320 Rethinking Marketing Programs for Emerging Markets & $\begin{array}{l}\text { Niraj Dawar and Amitava } \\
\text { Chattopadhyay }\end{array}$ & June 2000 \\
\hline $\begin{array}{l}\text { No. } 319 \text { Public Finance and Low Equilibria in Transition Economies: } \\
\text { the Role of Institutions }\end{array}$ & $\begin{array}{l}\text { Daniel Daianu and Radu } \\
\text { Vranceanu }\end{array}$ & June 2000 \\
\hline $\begin{array}{l}\text { No. } 318 \text { Some Econometric Evidence on the Effectiveness of Active } \\
\text { Labour Market Programmes in East Germany }\end{array}$ & $\begin{array}{l}\text { Martin Eichler and Michael } \\
\text { Lechner }\end{array}$ & June 2000 \\
\hline No. 317 A Model of Russia's "Virtual Economy" & R.E Ericson and B.W Ickes & May 2000 \\
\hline $\begin{array}{l}\text { No. } 316 \text { Financial Institutions, Financial Contagion, and Financial } \\
\text { Crises }\end{array}$ & $\begin{array}{l}\text { Haizhou Huang and Chenggang } \\
\mathrm{Xu}\end{array}$ & Mar. 2000 \\
\hline $\begin{array}{l}\text { No. } 315 \text { Privatization versus Regulation in Developing Economies: The } \\
\text { Case of West African Banks }\end{array}$ & $\begin{array}{l}\text { Jean Paul Azam, Bruno Biais, and } \\
\text { Magueye Dia }\end{array}$ & Feb. 2000 \\
\hline $\begin{array}{l}\text { No. } 314 \text { Is Life More Risky in the Open? Household Risk-Coping and } \\
\text { the Opening of China's Labor Markets }\end{array}$ & John Giles & Apr. 2000 \\
\hline $\begin{array}{l}\text { No. } 313 \text { Networks, Migration and Investment: Insiders and Outsiders in } \\
\text { Tirupur's Production Cluster }\end{array}$ & $\begin{array}{l}\text { Abhijit Banerjee and Kaivan } \\
\text { Munshi }\end{array}$ & Mar. 2000 \\
\hline $\begin{array}{l}\text { No. } 312 \text { Computational Analysis of the Impact on India of the Uruguay } \\
\text { Round and the Forthcoming WTO Trade Negotiations }\end{array}$ & $\begin{array}{l}\text { Rajesh Chadha, Drusilla K. } \\
\text { Brown, Alan V. Deardorff and } \\
\text { Robert M. Stern }\end{array}$ & Mar. 2000 \\
\hline No. 311 Subsidized Jobs for Unemployed Workers in Slovakia & Jan. C. van Ours & May 2000 \\
\hline No. 310 Determinants of Managerial Pay in the Czech Republic & $\begin{array}{l}\text { Tor Eriksson, Jaromir Gottvald } \\
\text { and Pavel Mrazek }\end{array}$ & May 2000 \\
\hline $\begin{array}{l}\text { No. } 309 \text { The Great Human Capital Reallocation: An Empirical Analysis } \\
\text { of Occupational Mobility in Transitional Russia }\end{array}$ & Klara Z. Sabirianova & Oct. 2000 \\
\hline No. 308 Economic Development, Legality, and the Transplant Effect & $\begin{array}{l}\text { Daniel Berkowitz, Katharina } \\
\text { Pistor, and Jean-Francois Richard }\end{array}$ & Feb. 2000 \\
\hline $\begin{array}{l}\text { No. } 307 \text { Community Participation, Teacher Effort, and Educational } \\
\text { Outcome: The Case of El Salvador's EDUCO Program }\end{array}$ & Yasuyuki Sawada & Nov. 1999 \\
\hline No. 306 Gender Wage Gap and Segregation in Late Transition & Stepan Jurajda & May 2000 \\
\hline $\begin{array}{l}\text { No. } 305 \text { The Gender Pay Gap in the Transition from Communism: } \\
\text { Some Empirical Evidence }\end{array}$ & Andrew Newell and Barry Reilly & May 2000 \\
\hline No. 304 Post-Unification Wage Growth in East Germany & Jennifer Hunt & Nov. 1998 \\
\hline $\begin{array}{l}\text { No. } 303 \text { How Does Privatization Affect Workers? The Case of the } \\
\text { Russian Mass Privatization Program }\end{array}$ & Elizabeth Brainerd & May 2000 \\
\hline $\begin{array}{l}\text { No. } 302 \text { Liability for Past Environmental Contamination and } \\
\text { Privatization }\end{array}$ & Dietrich Earnhart & Mar. 2000 \\
\hline No. 301 Varieties, Jobs and EU Enlargement & $\begin{array}{l}\text { Tito Boeri and Joaquim Oliveira } \\
\text { Martins }\end{array}$ & May 2000 \\
\hline No. 300 Employer Size Effects in Russia & Todd Idson & Apr. 2000 \\
\hline $\begin{array}{l}\text { No. } 299 \text { Information Complements, Substitutes, and Strategic Product } \\
\text { Design }\end{array}$ & $\begin{array}{l}\text { Geoffrey G. Parker and Marshall } \\
\text { W. Van Alstyne }\end{array}$ & Mar. 2000 \\
\hline $\begin{array}{l}\text { No. } 298 \text { Markets, Human Capital, and Inequality: Evidence from Rural } \\
\text { China }\end{array}$ & $\begin{array}{l}\text { Dwayne Benjamin, Loren Brandt, } \\
\text { Paul Glewwe, and Li Guo }\end{array}$ & May 2000 \\
\hline
\end{tabular}


Davidson Institute Working Papers are available at: www.wdi.bus.umich.edu

\begin{tabular}{|c|c|c|}
\hline No. 297 Corporate Governance in the Asian Financial Crisis & $\begin{array}{l}\text { Simon Johnson, Peter Boone, } \\
\text { Alasdair Breach, and Eric } \\
\text { Friedman }\end{array}$ & Nov. 1999 \\
\hline No. 296 Competition and Firm Performance: Lessons from Russia & J. David Brown and John S. Earle & Mar. 2000 \\
\hline No. 295 Wage Determination in Russia: An Econometric Investigation & $\begin{array}{l}\text { Peter J. Luke and Mark E. } \\
\text { Schaffer }\end{array}$ & Mar. 2000 \\
\hline $\begin{array}{l}\text { No. 294: Can Banks Promote Enterprise Restructuring?: Evidence From } \\
\text { a Polish Bank's Experience }\end{array}$ & John P. Bonin and Bozena Leven & Mar. 2000 \\
\hline No. 293: Why do Governments Sell Privatised Companies Abroad? & $\begin{array}{l}\text { Bernardo Bortolotti, Marcella } \\
\text { Fantini and Carlo Scarpa }\end{array}$ & Mar. 2000 \\
\hline $\begin{array}{l}\text { No. 292: Going Public in Poland: Case-by-Case Privatizations, Mass } \\
\text { Privatization and Private Sector Initial Public Offerings }\end{array}$ & Wolfgang Aussenegg & Dec. 1999 \\
\hline $\begin{array}{l}\text { No. 291: Institutional Technology and the Chains of Trust: Capital } \\
\text { Markets and Privatization in Russia and the Czech Republic }\end{array}$ & Bruce Kogut and Andrew Spicer & Mar. 1999 \\
\hline No. 290: Banking Crises and Bank Rescues: The Effect of Reputation & Jenny Corbett and Janet Mitchell & Jan. 2000 \\
\hline $\begin{array}{l}\text { No. 289: Do Active Labor Market Policies Help Unemployed Workers } \\
\text { to Find and Keep Regular Jobs? }\end{array}$ & Jan C. van Ours & Feb. 2000 \\
\hline No. 288: Consumption Patterns of the New Elite in Zimbabwe & Russell Belk & Feb. 2000 \\
\hline $\begin{array}{l}\text { No. 287: Barter in Transition Economies: Competing Explanations } \\
\text { Confront Ukranian Data }\end{array}$ & $\begin{array}{l}\text { Dalia Marin, Daniel Kaufmann } \\
\text { and Bogdan Gorochowskij }\end{array}$ & Jan. 2000 \\
\hline $\begin{array}{l}\text { No. 286: The Quest for Pension Reform: Poland's Security through } \\
\text { Diversity }\end{array}$ & $\begin{array}{l}\text { Marek Góra and Michael } \\
\text { Rutkowski }\end{array}$ & Jan. 2000 \\
\hline No. 285: Disorganization and Financial Collapse & $\begin{array}{l}\text { Dalia Marin and Monika } \\
\text { Schnitzer }\end{array}$ & Oct. 1999 \\
\hline No. 284: Coordinating Changes in M-form and U-form Organizations & $\begin{array}{l}\text { Yingyi Qian, Gérard Roland and } \\
\text { Chenggang Xu }\end{array}$ & May 1999 \\
\hline $\begin{array}{l}\text { No. 283: Why Russian Workers Do Not Move: Attachment of Workers } \\
\text { Through In-Kind Payments }\end{array}$ & Guido Friebel and Sergei Guriev & Oct. 1999 \\
\hline No. 282: Lessons From Fiascos in Russian Corporate Governance & $\begin{array}{l}\text { Merritt B. Fox and Michael A. } \\
\text { Heller }\end{array}$ & Oct. 1999 \\
\hline $\begin{array}{l}\text { No. 281: Income Distribution and Price Controls: Targeting a Social } \\
\text { Safety Net During Economic Transition }\end{array}$ & $\begin{array}{l}\text { Michael Alexeev and James } \\
\text { Leitzel }\end{array}$ & Mar. 1999 \\
\hline $\begin{array}{l}\text { No. 280: Starting Positions, Reform Speed, and Economic Outcomes in } \\
\text { Transitioning Economies }\end{array}$ & William Hallagan and Zhang Jun & Jan. 2000 \\
\hline No. 279 : The Value of Prominent Directors & $\begin{array}{l}\text { Yoshiro Miwa \& J. Mark } \\
\text { Ramseyer }\end{array}$ & Oct. 1999 \\
\hline No. 278: The System Paradigm & János Kornai & Apr. 1998 \\
\hline $\begin{array}{l}\text { No. 277: The Developmental Consequences of Foreign Direct } \\
\text { Investment in the Transition from Socialism to Capitalism: The } \\
\text { Performance of Foreign Owned Firms in Hungary }\end{array}$ & Lawrence Peter King & Sept. 1999 \\
\hline $\begin{array}{l}\text { No. 276: Stability and Disorder: An Evolutionary Analysis of Russia's } \\
\text { Virtual Economy }\end{array}$ & $\begin{array}{l}\text { Clifford Gaddy and Barry W. } \\
\text { Ickes }\end{array}$ & Nov. 1999 \\
\hline $\begin{array}{l}\text { No. 275: Limiting Government Predation Through Anonymous } \\
\text { Banking: A Theory with Evidence from China. }\end{array}$ & $\begin{array}{l}\text { Chong-En Bai, David D. Li, } \\
\text { Yingyi Qian and Yijiang Wang }\end{array}$ & July 1999 \\
\hline No. 274: Transition with Labour Supply & Tito Boeri & Dec. 1999 \\
\hline $\begin{array}{l}\text { No. 273: Sectoral Restructuring and Labor Mobility: A Comparative } \\
\text { Look at the Czech Republic }\end{array}$ & Vit Sorm and Katherine Terrell & Nov. 1999 \\
\hline $\begin{array}{l}\text { No. 272: Published in: Journal of Comparative Economics "Returns to } \\
\text { Human Capital Under the Communist Wage Grid and During the } \\
\text { Transition to a Market Economy" Vol. 27, pp. 33-60 } 1999 .\end{array}$ & $\begin{array}{l}\text { Daniel Munich, Jan Svejnar and } \\
\text { Katherine Terrell }\end{array}$ & Oct. 1999 \\
\hline $\begin{array}{l}\text { No. 271: Barter in Russia: Liquidity Shortage Versus Lack of } \\
\text { Restructuring }\end{array}$ & $\begin{array}{l}\text { Sophie Brana and Mathilde } \\
\text { Maurel }\end{array}$ & June 1999 \\
\hline $\begin{array}{l}\text { No. 270: Tests for Efficient Financial Intermediation with Application to } \\
\text { China }\end{array}$ & Albert Park and Kaja Sehrt & Mar. 1999 \\
\hline $\begin{array}{l}\text { No. 269a: Russian Privatization and Corporate Governance: What Went } \\
\text { Wrong? }\end{array}$ & $\begin{array}{l}\text { Bernard Black, Reinier Kraakman } \\
\text { and Anna Tarassova }\end{array}$ & May 2000 \\
\hline
\end{tabular}




\begin{tabular}{|c|c|c|}
\hline $\begin{array}{l}\text { No. 269: Russian Privatization and Corporate Governance: What Went } \\
\text { Wrong? }\end{array}$ & $\begin{array}{l}\text { Bernard Black, Reinier Kraakman } \\
\text { and Anna Tarassova }\end{array}$ & Sept. 1999 \\
\hline No. 268: Are Russians Really Ready for Capitalism? & Susan Linz & Sept. 1999 \\
\hline No. 267: Do Stock Markets Promote Economic Growth? & $\begin{array}{l}\text { Randall K. Filer, Jan Hanousek } \\
\text { and Nauro Campos }\end{array}$ & Sept. 1999 \\
\hline $\begin{array}{l}\text { No. 266: Objectivity, Proximity and Adaptability in Corporate } \\
\text { Governance }\end{array}$ & $\begin{array}{l}\text { Arnoud W.A Boot and Jonathan } \\
\text { R. Macey }\end{array}$ & Sept. 1999 \\
\hline $\begin{array}{l}\text { No. 265: When the Future is not What it Used to Be: Lessons from the } \\
\text { Western European Experience to Forecasting Education and Training in } \\
\text { Transitional Economies }\end{array}$ & $\begin{array}{l}\text { Nauro F. Campos, Gerard } \\
\text { Hughes, Stepan Jurajda, and } \\
\text { Daniel Munich }\end{array}$ & Sept. 1999 \\
\hline $\begin{array}{l}\text { No. 264: The Institutional Foundation of Foreign-Invested Enterprises } \\
\text { (FIEs) in China }\end{array}$ & Yasheng Huang & Sept. 1999 \\
\hline $\begin{array}{l}\text { No. 263: The Changing Corporate Governance Paradigm: Implications } \\
\text { for Transition and Developing Countries }\end{array}$ & $\begin{array}{l}\text { Erik Berglof and Ernst-Ludwig } \\
\text { von Thadden }\end{array}$ & June 1999 \\
\hline No. 262: Law Enforcement and Transition & $\begin{array}{l}\text { Gerard Roland and Thierry } \\
\text { Verdier }\end{array}$ & May 1999 \\
\hline $\begin{array}{l}\text { No. 261: Soft Budget Constraints, Pecuniary Externality, and the Dual } \\
\text { Track System }\end{array}$ & Jiahua Che & June 2000 \\
\hline $\begin{array}{l}\text { No. 260: Missing Market in Labor Quality: The Role of Quality Markets } \\
\text { in Transition }\end{array}$ & Gary H. Jefferson & July 1999 \\
\hline $\begin{array}{l}\text { No. 259: Do Corporate Global Environmental Standards in Emerging } \\
\text { Markets Create or Destroy Market Value }\end{array}$ & $\begin{array}{l}\text { Glen Dowell, Stuart Hart and } \\
\text { Bernard Yeung }\end{array}$ & June 1999 \\
\hline No. 258: Public Training and Outflows from Unemployment & Patrick A. Puhani & June 1999 \\
\hline $\begin{array}{l}\text { No. 257: Ownership Versus Environment: Why are Public Sector Firms } \\
\text { Inefficient? }\end{array}$ & $\begin{array}{l}\text { Ann P. Bartel and Ann E. } \\
\text { Harrison }\end{array}$ & June 1999 \\
\hline $\begin{array}{l}\text { No. 256: Taxation and Evasion in the Presence of Exortion by } \\
\text { Organized Crime }\end{array}$ & $\begin{array}{l}\text { Michael Alexeev, Eckhard Janeba } \\
\text { and Stefan Osborne }\end{array}$ & Nov. 1999 \\
\hline No. 255: Revisiting Hungary’s Bankruptcy Episode & $\begin{array}{l}\text { John P. Bonin and Mark E. } \\
\text { Schaffer }\end{array}$ & Sept. 1999 \\
\hline No. 254: FDI in Emerging Markets: A Home-Country View & Marina v.N Whitman & June 1999 \\
\hline $\begin{array}{l}\text { No. 253: The Asian Financial Crisis: What Happened, and What is to be } \\
\text { Done }\end{array}$ & $\begin{array}{l}\text { Jeffrey D. Sachs and Wing Thye } \\
\text { Woo }\end{array}$ & Jan. 1999 \\
\hline No. 252: Organizational Law as Asset Partitioning & $\begin{array}{l}\text { Henry Hansmann and Reinier } \\
\text { Kraakman }\end{array}$ & Sept. 1999 \\
\hline $\begin{array}{l}\text { No. 251: Consumer Behavior Research in Emerging Consumer Markets: } \\
\text { the Case of the Optimum Stimulation Level in South Africa }\end{array}$ & $\begin{array}{l}\text { Jan-Benedict E. M. Steenkamp } \\
\text { and Steven M. Burgess }\end{array}$ & Sept. 1999 \\
\hline $\begin{array}{l}\text { No. 250: Property Rights Formation and the Organization of Exchange } \\
\text { and Production in Rural China }\end{array}$ & $\begin{array}{l}\text { Matthew A. Turner, Loren } \\
\text { Brandt, and Scott Rozelle }\end{array}$ & July 1998 \\
\hline $\begin{array}{l}\text { No. 249: Impacts of the Indonesian Economic Crisis: Price Changes and } \\
\text { the Poor }\end{array}$ & $\begin{array}{l}\text { James Levinsohn, Steven Berry, } \\
\text { and Jed Friedman }\end{array}$ & June 1999 \\
\hline $\begin{array}{l}\text { No. 248: Internal Barriers in the Transition of Enterprises from Central } \\
\text { Plan to Market }\end{array}$ & Charalambos Vlachoutsicos & July 1999 \\
\hline $\begin{array}{l}\text { No. 247: Spillovers from Multinationals in Developing Countries: the } \\
\text { Mechanisms at Work }\end{array}$ & Richard E. Caves & June 1999 \\
\hline $\begin{array}{l}\text { No. 246: Dynamism and Inertia on the Russian Labour Market: A } \\
\text { Model of Segmentation }\end{array}$ & $\begin{array}{l}\text { Irena Grosfeld, Claudia Senik- } \\
\text { Leygonie, Thierry Verdier, Stanislav } \\
\text { Kolenikov and Elena Paltseva }\end{array}$ & May 1999 \\
\hline No. 245: Lessons from Bank Privatization in Central Europe & John Bonin and Paul Wachtel & May 1999 \\
\hline $\begin{array}{l}\text { No. 244: Nominal-Real Tradeoffs and the Effects of Monetary Policy: } \\
\text { the Romanian Experience }\end{array}$ & Christian Popa & Dec. 1998 \\
\hline $\begin{array}{l}\text { No. 243: Privatization, Political Risk and Stock Market Development in } \\
\text { Emerging Economies }\end{array}$ & $\begin{array}{l}\text { Enrico C. Perotti and Pieter van } \\
\text { Oijen }\end{array}$ & Mar. 1999 \\
\hline No. 242: Investment Financing in Russian Financial-Industrial Groups & $\begin{array}{l}\text { Enrico C. Perotti and Stanislav } \\
\text { Gelfer }\end{array}$ & Oct. 1998 \\
\hline $\begin{array}{l}\text { No. 241: Can governments maintain hard budget constraints? Bank } \\
\text { lending and financial isolation in Romania }\end{array}$ & $\begin{array}{l}\text { Octavian Carare, Constantijn } \\
\text { Claessens, Enrico C. Perotti }\end{array}$ & Jan. 1999 \\
\hline
\end{tabular}




\begin{tabular}{|c|c|c|}
\hline $\begin{array}{l}\text { No. 240: Democratic Institutions and Economic Reform: the Polish } \\
\text { Case }\end{array}$ & $\begin{array}{l}\text { John E. Jackson, Jacek Klich, and } \\
\text { Krystyna Poznanska }\end{array}$ & Apr. 1998 \\
\hline No. 239: A Longitudinal Study of IJV Performance in Eastern Europe & $\begin{array}{l}\text { Keith D. Brouthers and Gary } \\
\text { Bamossy }\end{array}$ & June 1999 \\
\hline $\begin{array}{l}\text { No. 238: Published in: Journal of Business Venturing, "Firm Creation } \\
\text { and Economic Transitions" } 14(5,6) \text { Sep/Nov 1999, pp. 427-450. }\end{array}$ & $\begin{array}{l}\text { John E. Jackson, Jacek Klich, } \\
\text { Krystyna Poznanska }\end{array}$ & July 1998 \\
\hline No. 237: Analysis of Entrepreneurial Attitudes in Poland & $\begin{array}{l}\text { John E. Jackson and Aleksander } \\
\text { S. Marcinkowski }\end{array}$ & Mar. 1997 \\
\hline $\begin{array}{l}\text { No. 236: Investment and Finance in De Novo Private Firms: Empirical } \\
\text { Results from the Czech Republic, Hungary, and Poland }\end{array}$ & $\begin{array}{l}\text { Andrzej Bratkowski, Irena } \\
\text { Grosfeld, Jacek Rostowski }\end{array}$ & Apr. 1999 \\
\hline $\begin{array}{l}\text { No. 235: Does a Soft Macroeconomic Environment Induce } \\
\text { Restructuring on the Microeconomic Level during the Transition } \\
\text { Period? Evidence from Investment Behavior of Czech Enterprises }\end{array}$ & Lubomír Lízal & June 1999 \\
\hline $\begin{array}{l}\text { No. 234: Banking Reform in China: Gradually Strengthening Pillar or } \\
\text { Fragile Reed? }\end{array}$ & John Bonin & June 1999 \\
\hline $\begin{array}{l}\text { No. 233: Theories of Soft Budget Constraints and the Analysis of } \\
\text { Banking Crises }\end{array}$ & Janet Mitchell & Mar. 1999 \\
\hline $\begin{array}{l}\text { No. 232: Unemployment Risk, Precautionary Savings, and } \\
\text { Moonlighting in Russia }\end{array}$ & $\begin{array}{l}\text { Alessandra Guariglia and Byung- } \\
\text { Yeon Kim }\end{array}$ & June 1999 \\
\hline $\begin{array}{l}\text { No. 231: Investing in Turbulent Times: The Investment Behavior of } \\
\text { Polish Firms in the Transition }\end{array}$ & $\begin{array}{l}\text { Josef C. Brada, Arthur E. King, } \\
\text { and Chia-Ying Ma }\end{array}$ & Apr. 1999 \\
\hline No. 230: The End of Moderate Inflation in Three Transition Economies? & Josef C. Brada and Ali M. Kutan & Apr. 1999 \\
\hline $\begin{array}{l}\text { No. 229: Back to the Future: The Growth Prospects of Transition } \\
\text { Economies Reconsidered }\end{array}$ & Nauro F. Campos & Apr. 1999 \\
\hline No. 228: The Enterprise Isolation Program in Russia & Simeon Djankov & Apr. 1999 \\
\hline $\begin{array}{l}\text { No. 227: Published in: Journal of Comparative Economics, "Ownership } \\
\text { Concentration and Corporate Performance in the Czech Republic" } \\
\text { 27(3), Sept. 1999, pp. 498-513. }\end{array}$ & $\begin{array}{l}\text { Stijn Claessens and Simeon } \\
\text { Djankov }\end{array}$ & Apr. 1999 \\
\hline $\begin{array}{l}\text { No. 226: Published in Journal of Population Economics, "Poland on the } \\
\text { Dole: The Effect of Reducing the Unemployment Benefit Entitlement } \\
\text { Period during Transition" 13:35-44, } 2000 \text {. }\end{array}$ & Patrick A. Puhani & Mar. 1999 \\
\hline No. 225: Transition at Whirlpool-Tatramat: Case Studies & $\begin{array}{l}\text { Hans Brechbuhl and Sonia } \\
\text { Ferencikova }\end{array}$ & Mar. 1999 \\
\hline $\begin{array}{l}\text { No. 224: Measuring Progress in Transition and Towards EU Accession: } \\
\text { A Comparison of Manufacturing Firms in Poland, Romania, and Spain }\end{array}$ & $\begin{array}{l}\text { Wendy Carlin, Saul Estrin, and } \\
\text { Mark Schaffer }\end{array}$ & Mar. 1999 \\
\hline $\begin{array}{l}\text { No. 223: Product Market Competition in Transition Economies: } \\
\text { Increasing Varieties and Consumer Loyalty }\end{array}$ & Mitsutoshi M. Adachi & Mar. 1999 \\
\hline $\begin{array}{l}\text { No. 222: Opaque Markets and Rapid Growth: the Superiority of Bank- } \\
\text { Centered Financial Systems for Developing Nations }\end{array}$ & Rodney Wallace & July 1999 \\
\hline No. 221: Technology Spillovers through Foreign Direct Investment & Yuko Kinoshita & Jan. 1999 \\
\hline $\begin{array}{l}\text { No. 220: Managerial, Expertise and Team Centered Forms of } \\
\text { Organizing: A Cross-Cultural Exploration of Independence in } \\
\text { Engineering Work }\end{array}$ & Leslie Perlow & Jan. 1999 \\
\hline $\begin{array}{l}\text { No. 219: Household Structure and Labor Demand in Agriculture: } \\
\text { Testing for Separability in Rural China }\end{array}$ & $\begin{array}{l}\text { Audra J. Bowlus and Terry } \\
\text { Sicular }\end{array}$ & Jan. 1999 \\
\hline $\begin{array}{l}\text { No. 218: Competing Strategies of FDI and Technology Transfer to } \\
\text { China: American and Japanese Firms }\end{array}$ & $\begin{array}{l}\text { W. Mark Fruin and Penelope } \\
\text { Prime }\end{array}$ & Jan. 1999 \\
\hline $\begin{array}{l}\text { No. } 217 \text { Published in: Journal of Comparative Economics, "Returns to } \\
\text { Mobility in the Transition to a Market Economy" 27(1), Mar } 1999 .\end{array}$ & $\begin{array}{l}\text { Tito Boeri and Christopher J. } \\
\text { Flinn }\end{array}$ & Jan. 1999 \\
\hline $\begin{array}{l}\text { No. } 216 \text { Published in: Journal of Comparative Economics, "Labor } \\
\text { Market Policies and Unemployment in the Czech Republic." 27(1), Mar } \\
\text { 1999, pp. 33-60. }\end{array}$ & Katherine Terrell and Vit Sorm & Nov. 1998 \\
\hline $\begin{array}{l}\text { No. } 215 \text { Published in: Journal of Comparative Economics, "Active } \\
\text { Labor Market Policies in Poland: Human Capital Enhancement, } \\
\text { Stigmatization or Benefit Churning?" 27(1), Mar 1999, pp. 61-. }\end{array}$ & $\begin{array}{l}\text { Jochen Kluve, Hartmut Lehmann, } \\
\text { and Christoph M. Schmidt }\end{array}$ & Dec. 1998 \\
\hline
\end{tabular}




\begin{tabular}{|c|c|c|}
\hline $\begin{array}{l}\text { No. } 214 \text { Published in: Journal of Comparative Economics, "Does the } \\
\text { Slovenian Public Work Program Increase Participants' Chances to Find } \\
\text { a Job?" 27(1), Mar 1999, pp. 113- . }\end{array}$ & Milan Vodopivec & Dec. 1998 \\
\hline $\begin{array}{l}\text { No. } 213 \text { Published in: Journal of Comparative Economics, "Effects of } \\
\text { Active Labor Market Programs on the Transition Rate from } \\
\text { Unemployment into Regular Jobs in the Slovak Republic." 27(1), Mar } \\
\text { 1999, pp. 90- . }\end{array}$ & $\begin{array}{l}\text { Martina Lubyova and Jan C. van } \\
\text { Ours }\end{array}$ & Dec. 1998 \\
\hline $\begin{array}{l}\text { No. 212: The Marketing System in Bulgarian Livestock Production - } \\
\text { The Present State and Evolutionary Processes During the Period of } \\
\text { Economic Transition }\end{array}$ & Yordan Staykov, Team Leader & Oct. 1998 \\
\hline No. 211: Bankruptcy Experience in Hungary and the Czech Republic & Janet Mitchell & Oct. 1998 \\
\hline $\begin{array}{l}\text { No 210: Values, Optimum Stimulation Levels and Brand Loyalty: New } \\
\text { Scales in New Populations }\end{array}$ & $\begin{array}{l}\text { Steven M. Burgess and Mari } \\
\text { Harris }\end{array}$ & Sept. 1998 \\
\hline No. 209: Inherited Wealth, Corporate Control and Economic Growth & $\begin{array}{l}\text { Randall K. Morck, David A. } \\
\text { Stangeland, and Bernard Yeung }\end{array}$ & Sept. 1998 \\
\hline $\begin{array}{l}\text { No. 208: A Cultural Analysis of Homosocial Reproduction and } \\
\text { Contesting Claims to Competence in Transitional Firms }\end{array}$ & Michael D. Kennedy & July 1998 \\
\hline $\begin{array}{l}\text { No. 207: From Survival to Success: The Journey of Corporate } \\
\text { Transformation at Haier. Forthcoming in Managing Organizational } \\
\text { Change in Transition Economies ed. Daniel Denison. }\end{array}$ & $\begin{array}{l}\text { Arthur Yeung and Kenneth } \\
\text { DeWoskin }\end{array}$ & July 1998 \\
\hline $\begin{array}{l}\text { No. 206: Why Do People Work If They Are Not Paid? An Example } \\
\text { from Eastern Europe. Forthcoming in Managing Organizational Change } \\
\text { in Transition Economies. }\end{array}$ & Irina L. Zinovieva & May 1998 \\
\hline $\begin{array}{l}\text { No. 205: Firm Ownership and Work Motivation in Bulgaria and } \\
\text { Hungary: An Empirical Study of the Transition in the Mid-1990s. } \\
\text { Forthcoming in Managing Organizational Change in Transition } \\
\text { Economies ed. Daniel Denison. }\end{array}$ & $\begin{array}{l}\text { Robert A. Roe, Irina L. } \\
\text { Zinovieva, Elizabeth Dienes, and } \\
\text { Laurens A. ten Horn }\end{array}$ & May 1998 \\
\hline $\begin{array}{l}\text { No. 204: Human Resource Management in the Restructuring of Chinese } \\
\text { Joint Ventures. Forthcoming in Managing Organizational Change in } \\
\text { Transition Economies ed. Daniel Denison. }\end{array}$ & Nandani Lynton & Apr. 1998 \\
\hline $\begin{array}{l}\text { No. 203: Emergent Compensation Strategies in Post-Socialist Poland: } \\
\text { Understanding the Cognitive Underpinnings of Management Practices } \\
\text { in a Transition Economy. Forthcoming in Managing Organizational } \\
\text { Change in Transition Economies ed. Daniel Denison. }\end{array}$ & Marc Weinstein & Mar. 1998 \\
\hline $\begin{array}{l}\text { No. 202: Corporate Transformation and Organizational Learning: The } \\
\text { People's Republic of China. Forthcoming in Managing Organizational } \\
\text { Change in Transition Economies ed. Daniel Denison. }\end{array}$ & $\begin{array}{l}\text { Meinolf Dierkes and Zhang } \\
\text { Xinhua }\end{array}$ & Mar. 1998 \\
\hline $\begin{array}{l}\text { No. 201: Foreign Direct Investment as a Factor of Change: The Case of } \\
\text { Slovakia. Forthcoming in Managing Organizational Change in } \\
\text { Transition Economies ed. Daniel Denison. }\end{array}$ & Sonia Ferencikova & Feb. 1998 \\
\hline $\begin{array}{l}\text { No. 200: Radical versus Incremental Change: The Role of Capabilities, } \\
\text { Competition, and Leaders. Forthcoming in Managing Organizational } \\
\text { Change in Transition Economies ed. Daniel Denison. }\end{array}$ & Karen L. Newman & Feb. 1998 \\
\hline $\begin{array}{l}\text { No. 199: The Emergence of Market Practices in China's Economic } \\
\text { Transition: Price Setting Practices in Shanghai’s Industrial Firms. } \\
\text { Forthcoming in Managing Organizational Change in Transition } \\
\text { Economies ed. Daniel Denison. }\end{array}$ & Douglas Guthrie & Feb. 1998 \\
\hline $\begin{array}{l}\text { No. 198: The Application of Change Management Methods at Business } \\
\text { Organizations Operating in Hungary: Challenges in the Business and } \\
\text { Cultural Environment and First Practical Experiences. Forthcoming in } \\
\text { Managing Organizational Change in Transition Economies ed. Daniel } \\
\text { Denison. }\end{array}$ & Dr. János Fehér & Jan. 1998 \\
\hline $\begin{array}{l}\text { No. 197: Organizational Changes in Russian Industrial Enterprises: } \\
\text { Mutation of Decision-Making Structures and Transformations of } \\
\text { Ownership. Forthcoming in Managing Organizational Change in } \\
\text { Transition Economies ed. Daniel Denison. }\end{array}$ & Igor B. Gurkov & Jan. 1998 \\
\hline
\end{tabular}




\begin{tabular}{|c|c|c|}
\hline $\begin{array}{l}\text { No. 196: Understanding and Managing Challenges to the Romanian } \\
\text { Companies during Transition. Forthcoming in Managing Organizational } \\
\text { Change in Transition Economies ed. Daniel Denison. }\end{array}$ & $\begin{array}{l}\text { Dan Candea and Rodica M. } \\
\text { Candea }\end{array}$ & Jan. 1998 \\
\hline $\begin{array}{l}\text { No. 195: Insider Lending and Economic Transition: The Structure, } \\
\text { Function, and Performance Impact of Finance Companies in Chinese } \\
\text { Business Groups. Forthcoming in Managing Organizational Change in } \\
\text { Transition Economies ed. Daniel Denison. }\end{array}$ & Lisa A. Keister & Dec. 1997 \\
\hline $\begin{array}{l}\text { No. 194: Japanese Investment in Transitional Economies: } \\
\text { Characteristics and Performance. Forthcoming in Managing } \\
\text { Organizational Change in Transition Economies ed. Daniel Denison. }\end{array}$ & $\begin{array}{l}\text { Paul W. Beamish and Andrew } \\
\text { Delios }\end{array}$ & Nov. 1997 \\
\hline $\begin{array}{l}\text { No. 193: Building Successful Companies in Transition Economies. } \\
\text { Forthcoming in Managing Organizational Change in Transition } \\
\text { Economies ed. Daniel Denison. }\end{array}$ & Dr. Ivan Perlaki & Jan. 1998 \\
\hline $\begin{array}{l}\text { No. 192: Russian Communitariansim: An Invisible Fist in the } \\
\text { Transformation Process of Russia. Forthcoming in Managing } \\
\text { Organizational Change in Transition Economies ed. Daniel Denison. }\end{array}$ & Charalambos Vlachoutsicos & July 1998 \\
\hline No. 191: Teaching the Dinosaurs to Dance & Michal Cakrt & Sept. 1997 \\
\hline $\begin{array}{l}\text { No. 190: Strategic Restructuring: Making Capitalism in Post- } \\
\text { Communist Eastern Europe. Forthcoming in Managing Organizational } \\
\text { Change in Transition Economies ed. Daniel Denison. }\end{array}$ & Lawrence P. King & Sept. 1997 \\
\hline $\begin{array}{l}\text { No. 189: Published in: Regional Science and Urban Economics, } \\
\text { "Russia's Internal Border." 29(5), Sept. } 1999 .\end{array}$ & $\begin{array}{l}\text { Daniel Berkowitz and David N. } \\
\text { DeJong }\end{array}$ & July 1998 \\
\hline No. 187: Corporate Structure and Performance in Hungary & László Halpern and Gábor Kórsöi & July 1998 \\
\hline No. 186: Performance of Czech Companies by Ownership Structure & $\begin{array}{l}\text { Andrew Weiss and Georgiy } \\
\text { Nikitin }\end{array}$ & June 1998 \\
\hline $\begin{array}{l}\text { No. 185: Firm Performance in Bulgaria and Estonia: The effects of } \\
\text { competitive pressure, financial pressure and disorganisation }\end{array}$ & Jozef Konings & July 1998 \\
\hline $\begin{array}{l}\text { No. 184: Investment and Wages during the Transition: Evidence from } \\
\text { Slovene Firms }\end{array}$ & Janez Prasnikar and Jan Svejnar & July 1998 \\
\hline $\begin{array}{l}\text { No. 183: Investment Portfolio under Soft Budget: Implications for } \\
\text { Growth, Volatility and Savings }\end{array}$ & Chongen Bai and Yijiang Wang & July 1998 \\
\hline No. 181: Delegation and Delay in Bank Privatization & $\begin{array}{l}\text { Loránd Ambrus-Lakatos and } \\
\text { Ulrich Hege }\end{array}$ & July 1998 \\
\hline No. 180: Financing Mechanisms and R\&D Investment & $\begin{array}{l}\text { Haizhou Huang and Chenggang } \\
\mathrm{Xu}\end{array}$ & July 1998 \\
\hline $\begin{array}{l}\text { No. 179: Organizational Culture and Effectiveness: The Case of Foreign } \\
\text { Firms in Russia }\end{array}$ & $\begin{array}{l}\text { Carl F. Fey and Daniel R. } \\
\text { Denison }\end{array}$ & Jan. 1999 \\
\hline No. 178: Output and Unemployment Dynamics in Transition & $\begin{array}{l}\text { Vivek H. Dehejia and Douglas W. } \\
\text { Dwyer }\end{array}$ & Jan. 1998 \\
\hline $\begin{array}{l}\text { No. 177: Published in: Economics of Transition, "Bureaucracies in the } \\
\text { Russian Voucher Privatization." 8(1), 2000, pp. 37-57. }\end{array}$ & Guido Friebel & June 1998 \\
\hline No. 176: Chronic Moderate Inflation in Transition: The Tale of Hungary & János Vincze & June 1998 \\
\hline No. 175: Privatisation and Market Structure in a Transition Economy & John Bennett and James Maw & June 1998 \\
\hline $\begin{array}{l}\text { No. 174: Ownership and Managerial Competition: Employee, Customer, } \\
\text { or Outside Ownership }\end{array}$ & $\begin{array}{l}\text { Patrick Bolton and Chenggang } \\
\mathrm{Xu}\end{array}$ & June 1998 \\
\hline $\begin{array}{l}\text { No. 173: Intragovernment Procurement of Local Public Good: A } \\
\text { Theory of Decentralization in Nondemocratic Government }\end{array}$ & $\begin{array}{l}\text { Chong-en Bai, Yu Pan and } \\
\text { Yijiang Wang }\end{array}$ & June 1998 \\
\hline No. 172: Political Instability and Growth in Proprietary Economies & $\begin{array}{l}\text { Jody Overland and Michael } \\
\text { Spagat }\end{array}$ & Aug. 1998 \\
\hline $\begin{array}{l}\text { No. 171: Published in Post-Communist Economies, "Framework Issues } \\
\text { in the Privatization Strategies of the Czech Republic, Hungary, and } \\
\text { Poland" 11(1) Mar. } 1999 .\end{array}$ & Morris Bornstein & June 1998 \\
\hline $\begin{array}{l}\text { No. 170: Published in: European Journal of Political Economy } \\
\text { "Privatization, Ownership Structure and Transparency: How to Measure } \\
\text { a Real Involvement of the State" 15(4), Nov. 1999, pp. 605-18. }\end{array}$ & Frantisek Turnovec & May 1998 \\
\hline
\end{tabular}




\begin{tabular}{|c|c|c|}
\hline $\begin{array}{l}\text { No. } 169 \text { Published in: American Economic Review, "Unemployment and } \\
\text { the Social Safety Net during Transitions to a Market Economy: } \\
\text { Evidence from Czech and Slovak Men" 88(5), Dec 1998, pp. 1117-1142 }\end{array}$ & $\begin{array}{l}\text { John C. Ham, Jan Svejnar, and } \\
\text { Katherine Terrell }\end{array}$ & Dec. 1998 \\
\hline $\begin{array}{l}\text { No. 167: Voucher Privatization with Investment Funds: An Institutional } \\
\text { Analysis }\end{array}$ & David Ellerman & Mar. 1998 \\
\hline $\begin{array}{l}\text { No. 166: Published in: Marketing Issues in Transitional Economies, } \\
\text { "Value Priorities and Consumer Behavior in a Transitional Economy: } \\
\text { The Case of South Africa" ed. Rajeev Batra. }\end{array}$ & $\begin{array}{l}\text { Steven M. Burgess and Jan- } \\
\text { Benedict E.M. Steenkamp }\end{array}$ & Aug. 1998 \\
\hline $\begin{array}{l}\text { No. 164: Finance and Investment in Transition: Czech Enterprises, } \\
\text { 1993-1994 }\end{array}$ & $\begin{array}{l}\text { Ronald Anderson and Chantal } \\
\text { Kegels }\end{array}$ & Sept. 1997 \\
\hline $\begin{array}{l}\text { No. 163: European Union Trade and Investment Flows U-Shaping } \\
\text { Industrial Output in Central and Eastern Europe: Theory and Evidence }\end{array}$ & $\begin{array}{l}\text { Alexander Repkine and Patrick P. } \\
\text { Walsh }\end{array}$ & Apr. 1998 \\
\hline $\begin{array}{l}\text { No. 162: Skill Acquisition and Private Firm Creation in Transition } \\
\text { Economies }\end{array}$ & Zuzana Brixiova and Wenli Li & Oct. 1999 \\
\hline No. 161: Corruption in Transition & Susanto Basu and David D. Li & May 1998 \\
\hline $\begin{array}{l}\text { No. 160a: Tenures that Shook the World: Worker Turnover in Russia, } \\
\text { Poland and Britain }\end{array}$ & $\begin{array}{l}\text { Hartmut Lehmann and Jonathan } \\
\text { Wadsworth }\end{array}$ & Nov. 1999 \\
\hline $\begin{array}{l}\text { No. 160: Tenures that Shook the World: Worker Turnover in the } \\
\text { Russian Federation and Poland }\end{array}$ & $\begin{array}{l}\text { Hartmut Lehmann and Jonathan } \\
\text { Wadsworth }\end{array}$ & June 1998 \\
\hline No. 159: Does Market Structure Matter? New Evidence from Russia & $\begin{array}{l}\text { Annette N. Brown and J. David } \\
\text { Brown }\end{array}$ & June 1998 \\
\hline $\begin{array}{l}\text { No. 158: Structural Adjustment and Regional Long Term } \\
\text { Unemployment in Poland }\end{array}$ & $\begin{array}{l}\text { Hartmut Lehmann and Patrick P. } \\
\text { Walsh }\end{array}$ & June 1997 \\
\hline $\begin{array}{l}\text { No. 157: Baby Boom or Bust? Changing Fertility in Post-Communist } \\
\text { Czech Republic and Slovakia }\end{array}$ & Robert S. Chase & Apr. 1998 \\
\hline $\begin{array}{l}\text { No. } 156 \text { Published in: Leadership and Organization Development } \\
\text { Journal, "Leading Radical Change in Transition Economies." Vol. 19, } \\
\text { No. 6, 1998, pp. 309-324. }\end{array}$ & Karen L. Newman & June 1998 \\
\hline $\begin{array}{l}\text { No. } 155 \text { Published in: Oxford Review of Economic Policy, "From } \\
\text { Theory into Practice? Restructuring and Dynamism in Transition } \\
\text { Economies." Vol. 13, No. 2, Summer 1997, pp. 77-105. }\end{array}$ & $\begin{array}{l}\text { Wendy Carlin and Michael } \\
\text { Landesmann }\end{array}$ & June 1997 \\
\hline $\begin{array}{l}\text { No. 154: The Model and the Reality: Assessment of Vietnamese SOE } \\
\text { Reform-Implementation at the Firm Level }\end{array}$ & $\begin{array}{l}\text { Edmund Malesky, Vu Thanh } \\
\text { Hung, Vu Thi Dieu Anh, and } \\
\text { Nancy K. Napier }\end{array}$ & July 1998 \\
\hline $\begin{array}{l}\text { No. } 153 \text { Published in: Journal of Comparative Economics, "Causes of } \\
\text { the Soft Budget Constraint: Evidence on Three Explanations." Vol. 26, } \\
\text { No. 1, Mar. 1998, pp. 104-116. }\end{array}$ & David D. Li and Minsong Liang & Mar. 1998 \\
\hline $\begin{array}{l}\text { No. } 152 \text { Published in: Comparative Economic Studies, "Enterprise } \\
\text { Restructuring in Russia’s Transition Economy: Formal and Informal } \\
\text { Mechanisms." Vol. 40, No. 2, Summer 1998, pp. 5-52. }\end{array}$ & Susan J. Linz and Gary Krueger & Apr. 1998 \\
\hline $\begin{array}{l}\text { No. 151: Labor Productivity in Transition: A Regional Analysis of } \\
\text { Russian Industry }\end{array}$ & Susan J. Linz & May 1998 \\
\hline $\begin{array}{l}\text { No. 150: Tax Avoidance and the Allocation of Credit. Forthcoming in } \\
\text { Financial Systems in Transition: The Design of Financial Systems in } \\
\text { Central Europe eds. Anna Meyendorff and Anjan Thakor. }\end{array}$ & Anna Meyendorff & June 1998 \\
\hline $\begin{array}{l}\text { No. 149: Commitment, Versatility and Balance: Determinants of Work } \\
\text { Time Standards and Norms in a Multi-Country Study of Software } \\
\text { Engineers }\end{array}$ & Leslie Perlow and Ron Fortgang & Apr. 1998 \\
\hline $\begin{array}{l}\text { No. 148: Changes in Poland's Transfer Payments in the 1990s: the Fate } \\
\text { of Pensioners }\end{array}$ & Bozena Leven & June 1998 \\
\hline $\begin{array}{l}\text { No. 147: Environmental Protection and Economic Development: The } \\
\text { Case of the Huaihe River Basin Cleanup Plan }\end{array}$ & $\begin{array}{l}\text { Robert Letovsky, Reze Ramazani, } \\
\text { and Debra Murphy }\end{array}$ & June 1998 \\
\hline $\begin{array}{l}\text { No. 146: Chief Executive Compensation During Early Transition: } \\
\text { Further Evidence from Bulgaria }\end{array}$ & $\begin{array}{l}\text { Derek C. Jones, Takao Kato, and } \\
\text { Jeffrey Miller }\end{array}$ & June 1998 \\
\hline
\end{tabular}


No. 145 Published in: Economics of Transition, "Women's Unemployment During the Transition: Evidence from Czech and Slovak Micro Data," Vol. 7, No. 1, May 1999, pp. 47-78.

No. 144: Investment and Wages in Slovenia

No. 143 Published in: Review of Financial Studies, "Optimal

Bankruptcy Laws Across Different Economic Systems," 12(2), 47-77,

Summer 19993.

No. 142: Industrial Policy and Poverty in Transition Economies: Two

Steps Forward or One Step Back?

No. 141 Collective Ownership and Privatization of China's Village Enterprises

No. 140 A Comparative Look at Labor Mobility in the Czech Republic: Where have all the Workers Gone?

No. 139 The Failure of the Government-Led Program of Corporate

Reorganization in Romania

No. 138 Ownership and Employment in Russian Industry: 1992-1995

No. 137 Published in: Journal of Political Economy, "Reform Without

Losers: An Interpretation of China's Dual-Track Approach to

Transition," Feb. 2000; Vol. 108, Iss.1; pg. 120

No. 136 Published in: European Economic Review, "The Political

Economy of Mass Privatization and the Risk of Expropriation," 44(2),

Feb. 2000, pgs. 393-421

No. 135: Radical Organizational Change: The Role of Starting

Conditions, Competition, and Leaders

No. 134: To Restructure or Not to Restructure: Informal Activities and

Enterprise Behavior in Transition

No. 133: Management 101: Behavior of Firms in Transition Economies

No. 132 Published in: Quarterly Journal of Economics, "Interfirm

Relationships and Informal Credit in Vietnam," 114(4), Nov. 1999, pgs.

$1285-1320$

No. 131 Published in: Comparative Economic Studies, "Will

Restructuring Hungarian Companies Innovate? An Investigation Based

on Joseph Berliner's Analysis of Innovation in Soviet Industry." Vol.

40, No. 2, Summer 1998, pp. 53-74.

No. 130: Published in The American Economic Review, "Changing

Incentives of the Chinese Bureaucracy." May, 1998.

No. 129: Restructuring Investment in Transition: A Model of the

Enterprise Decision

No. 128 Published in: Comparative Economic Studies, "Job Rights in

Russian Firms: Endangered or Extinct Institutions?” Vol. 40, No. 4,

Winter 1998, pp. 1-32.

No. 127: Accounting for Growth in Post-Soviet Russia

No. 126 Published in: Economics of Transition, "From Federalism,

Chinese Style, to Privatization Chinese Style," 7(1), 1999, pgs. 103-31

No. 125: Market Discipline in Conglomerate Banks: Is an Internal

Allocation of Cost of Capital Necessary as Incentive Device?

Forthcoming in Financial Systems in Transition: The Design of

Financial Systems in Central Europe eds. Anna Meyendorff and Anjan

Thakor.

No. 124: Financial Discipline in the Enterprise Sector in Transition

Countries: How Does China Compare?

No. 123: Considerations of an Emerging Marketplace: Managers'

Perceptions in the Southern African Economic Community

No. 122: A Model of the Informal Economy in Transition Economies

\begin{tabular}{|c|c|}
\hline $\begin{array}{l}\text { John Ham, Jan Svejnar, and } \\
\text { Katherine Terrell }\end{array}$ & May 1998 \\
\hline Janez Prasnikar & May 1998 \\
\hline $\begin{array}{l}\text { Elazar Berkovitch and Ronen } \\
\text { Israel }\end{array}$ & Mar. 1998 \\
\hline Susan J. Linz & Mar. 1998 \\
\hline Suwen Pan and Albert Park & Apr. 1998 \\
\hline Vit Sorm and Katherine Terrell & Apr. 1999 \\
\hline $\begin{array}{l}\text { Simeon Djankov and Kosali } \\
\text { Ilayperuma }\end{array}$ & Sept. 1997 \\
\hline Susan J. Linz & Mar. 1998 \\
\hline $\begin{array}{l}\text { Lawrence J. Lau, Yingyi Qian, } \\
\text { and Gerard Roland }\end{array}$ & Nov. 1997 \\
\hline Klaus M. Schmidt & Mar. 1998 \\
\hline Karen L. Newman & Jan. 1998 \\
\hline $\begin{array}{l}\text { Clifford Gaddy and Barry W. } \\
\text { Ickes }\end{array}$ & May 1998 \\
\hline Josef C. Brada & Mar. 1998 \\
\hline $\begin{array}{l}\text { John McMillan and Christopher } \\
\text { Woodruff }\end{array}$ & Feb. 1998 \\
\hline John B. Bonin and Istvan Abel & Mar. 1998 \\
\hline David D. Li & Jan. 1998 \\
\hline Richard E. Ericson & Jan. 1998 \\
\hline Susan J. Linz & Jan. 1998 \\
\hline $\begin{array}{l}\text { Daniel Berkowitz and David N. } \\
\text { DeJong }\end{array}$ & Jan. 1998 \\
\hline $\begin{array}{l}\text { Yuanzheng Cao, Yingyi Qian, } \\
\text { and Barry R. Weingast }\end{array}$ & Dec. 1997 \\
\hline $\begin{array}{l}\text { Arnoud W. A. Boot and Anjolein } \\
\text { Schmeits }\end{array}$ & Nov. 1997 \\
\hline $\begin{array}{l}\text { Shumei Gao and Mark E. } \\
\text { Schaffer }\end{array}$ & Feb. 1998 \\
\hline Brent Chrite and David Hudson & Feb. 1998 \\
\hline $\begin{array}{l}\text { Simon Commander and Andrei } \\
\text { Tolstopiatenko }\end{array}$ & Nov. 1997 \\
\hline
\end{tabular}




\begin{tabular}{|c|c|c|}
\hline $\begin{array}{l}\text { No. 121: Local Labour Market Dynamics in the Czech and Slovak } \\
\text { Republics }\end{array}$ & $\begin{array}{l}\text { Peter Huber and Andreas } \\
\text { Worgotter }\end{array}$ & Nov. 1997 \\
\hline $\begin{array}{l}\text { No. 119: Published in Academy of Management Review, “Organizational } \\
\text { Transformation during Institutional Upheaval," } 25 \text { (3), 2000, p. 602-619 }\end{array}$ & Karen L. Newman & Mar. 1998 \\
\hline No. 118: Industrial Decline and Labor Reallocation in Romania & John S. Earle & Oct. 1997 \\
\hline No. 117: Notes for an Essay on the Soft Budget Constraint & Lorand Ambrus-Lakatos & Jan. 1997 \\
\hline No. 116: Labor Demand During Transition in Hungary & Gabor Korosi & Oct. 1997 \\
\hline No. 115: Enterprise Performance and Managers' Profiles & $\begin{array}{l}\text { Simeon Djankov and Stijn } \\
\text { Claessens }\end{array}$ & Dec. 1997 \\
\hline $\begin{array}{l}\text { No. 114b Employment and Wages in Enterprises under Communism } \\
\text { and in Transition: Evidence From Central Europe and Russia }\end{array}$ & $\begin{array}{l}\text { Swati Basu, Saul Estrin, and Jan } \\
\text { Svejnar }\end{array}$ & Apr. 2000 \\
\hline $\begin{array}{l}\text { No. 114: Employment and Wage Behavior of Enterprises in Transitional } \\
\text { Economies }\end{array}$ & $\begin{array}{l}\text { Swati Basu, Saul Estrin, and Jan } \\
\text { Svejnar }\end{array}$ & Oct. 1997 \\
\hline $\begin{array}{l}\text { No. 113: Preliminary Evidence on Active Labor Programs' Impact in } \\
\text { Hungary and Poland }\end{array}$ & Christopher J. O'Leary & Oct. 1997 \\
\hline $\begin{array}{l}\text { No. 111: Unemployment Benefits and Incentives in Hungary: New } \\
\text { Evidence }\end{array}$ & Joachim Wolff & Oct. 1997 \\
\hline $\begin{array}{l}\text { No. 110: Published in: Empirical Economics, "Long-Term } \\
\text { Unemployment, Unemployment Benefits and Social Assistance: The } \\
\text { Polish Experience" Empirical-Economics; 23(1-2), 1998, pp. 55-85. }\end{array}$ & $\begin{array}{l}\text { Marek Gora and Christoph M. } \\
\text { Schmidt }\end{array}$ & Apr. 1997 \\
\hline $\begin{array}{l}\text { No. } 109 \text { Published in: Industrial and Labor Relations Review, "Markets } \\
\text { for Communist Human Capital: Returns to Education and Experience in } \\
\text { Post-Communist Czech Republic and Slovakia." 51(3), Apr. 1998, pp. } \\
\text { 401-423. }\end{array}$ & Robert S. Chase & Oct. 1997 \\
\hline $\begin{array}{l}\text { No. 107: The Worker-Firm Matching in the Transition: (Why) Are the } \\
\text { Czechs More Successful Than Others? }\end{array}$ & $\begin{array}{l}\text { Daniel Münich, Jan Svejnar, and } \\
\text { Katherine Terrell }\end{array}$ & Oct. 1997 \\
\hline $\begin{array}{l}\text { No. } 106 \text { Published in: Journal of Comparative Economics, "Job } \\
\text { Creation, Job Destruction and Growth of Newly Established, Privatized } \\
\text { and State-Owned Enterprises in Transition Economies: Survey Evidence } \\
\text { from Bulgaria, Hungary, and Romania," 26(3), Sept. 1998, pp. 429-445. }\end{array}$ & $\begin{array}{l}\text { Valentijn Bilsen and Jozef } \\
\text { Konings }\end{array}$ & Sept. 1998 \\
\hline $\begin{array}{l}\text { No. 105: Getting Behind the East-West [German] Wage Differential: } \\
\text { Theory and Evidence }\end{array}$ & $\begin{array}{l}\text { Michael Burda and Christoph } \\
\text { Schmidt }\end{array}$ & May 1997 \\
\hline No. 104: The Birth of the "Wage Curve" in Hungary, 1989-95 & Gabor Kertesi and Janos Kollo & Oct. 1997 \\
\hline $\begin{array}{l}\text { No. 103: Published in: Journal of Comparative Economics, "Grime and } \\
\text { Punishment: Job Insecurity and Wage Arrears in the Russian } \\
\text { Federation" 27, 595-617 (1999). }\end{array}$ & $\begin{array}{l}\text { Hartmut Lehmann, Jonathan } \\
\text { Wadsworth, and Alessandro } \\
\text { Acquisti }\end{array}$ & Oct. 1997 \\
\hline No. 102: Social Networks in Transition & $\begin{array}{l}\text { Lorena Barberia, Simon Johnson, } \\
\text { and Daniel Kaufmann }\end{array}$ & Oct. 1997 \\
\hline $\begin{array}{l}\text { No. 101: Depreciation and Russian Corporate Finance: A Pragmatic } \\
\text { Approach to Surviving the Transition }\end{array}$ & Susan J. Linz & Nov. 1997 \\
\hline No. 100: Romanian Financial System Reform & $\begin{array}{l}\text { Anna Meyendorff and Anjan V. } \\
\text { Thakor }\end{array}$ & Nov. 1997 \\
\hline $\begin{array}{l}\text { No. 99: Proceedings of the Conference on Strategic Alliances in } \\
\text { Transitional Economies, held May 20, } 1997 \text { at the Davidson Institute }\end{array}$ & Edited by Cynthia Koch & May 1997 \\
\hline No. 98: Institutions, Strain and the Underground Economy & Daniel Daianu and Lucian Albu & Nov. 1997 \\
\hline No. 97: Structure and Strain in Explaining Inter-Enterprise Arrears & Daniel Daianu & Nov. 1997 \\
\hline $\begin{array}{l}\text { No. 96: Resource Misallocation and Strain: Explaining Shocks in Post- } \\
\text { Command Economies }\end{array}$ & Daniel Daianu & Nov. 1997 \\
\hline $\begin{array}{l}\text { No. 95: Published in: Finance-a-Uver, "Czech Money Market: Emerging } \\
\text { Links Among Interest Rates." 48(2) } 1998 \text { pp. 99-109. }\end{array}$ & $\begin{array}{l}\text { Jan Hanousek and Evzen } \\
\text { Kocenda }\end{array}$ & Nov. 1997 \\
\hline $\begin{array}{l}\text { No. 94: Pre-Reform Industry and the } \\
\text { State Monopsony in China }\end{array}$ & $\begin{array}{l}\text { Xiao-Yuan Dong and Louis } \\
\text { Putterman }\end{array}$ & Oct. 1997 \\
\hline $\begin{array}{l}\text { No. 93: China's State-Owned Enterprises } \\
\text { In the First Reform Decade: } \\
\text { An Analysis of a Declining Monopsony }\end{array}$ & $\begin{array}{l}\text { Xiao-Yuan Dong and Louis } \\
\text { Putterman }\end{array}$ & Oct. 1997 \\
\hline No. 92: Expatriate Management in the Czech Re & Richard B. Peterson & Sept. 1997 \\
\hline
\end{tabular}




\begin{tabular}{|c|c|c|}
\hline No. 91: China and the Idea of Economic Reform & Thomas G. Rawski & Apr. 1997 \\
\hline $\begin{array}{l}\text { No. } 90 \text { Published in: China Economic Review, “China's State Enterprise } \\
\text { Reform: An Overseas Perspective.” Vol. 8, Spring 1997, pp. 89-98. }\end{array}$ & Thomas G. Rawski & July 1997 \\
\hline $\begin{array}{l}\text { No. 89: The Economic Determinants of Internal Migration Flows in } \\
\text { Russia During Transition }\end{array}$ & Annette N. Brown & July 1997 \\
\hline $\begin{array}{l}\text { No. 88: Gender Wage Gaps in China's Labor Market: Size, Structure, } \\
\text { Trends }\end{array}$ & $\begin{array}{l}\text { Margaret Maurer-Fazio, Thomas } \\
\text { G. Rawski, and Wei Zhang }\end{array}$ & July 1997 \\
\hline No. 87: Privatisation in Central and Eastern Europe & Saul Estrin & June 1997 \\
\hline $\begin{array}{l}\text { No. 86: Published in : Economics of Transition, "The Effect of } \\
\text { Privatization on Wealth Distribution in Russia." v. 7, no. 2, 1999, pp. } \\
449-65\end{array}$ & Michael Alexeev & Feb. 1998 \\
\hline $\begin{array}{l}\text { No. 85: Was Privatization in Eastern Germany a Special Case? Some } \\
\text { Lessons from the Treuhand }\end{array}$ & Uwe Siegmund & Sept. 1997 \\
\hline No. 84: Start-ups and Transition & $\begin{array}{l}\text { Daniel M. Berkowitz and David J. } \\
\text { Cooper }\end{array}$ & Sept. 1997 \\
\hline $\begin{array}{l}\text { No. 83: Which Enterprises (Believe They) Have Soft Budgets after } \\
\text { Mass Privatization? Evidence from Mongolia }\end{array}$ & $\begin{array}{l}\text { James Anderson, Georges } \\
\text { Korsun, and Peter Murrell }\end{array}$ & Oct. 1997 \\
\hline $\begin{array}{l}\text { No. 82: Published in: European Economic Review, "Unemployment } \\
\text { Dynamics and the Restructuring of the Slovak Unemployment Benefit } \\
\text { System." Apr., } 1997 .\end{array}$ & $\begin{array}{l}\text { Martina Lubyova and Jan C. van } \\
\text { Ours }\end{array}$ & June 1997 \\
\hline No. 81: Determinants of Unemployment Duration in Russia & Mark C. Foley & Aug. 1997 \\
\hline No. 80: The Many Faces of Information Disclosure & $\begin{array}{l}\text { Arnoud W.A. Boot and Anjan V. } \\
\text { Thakor }\end{array}$ & Oct. 1997 \\
\hline $\begin{array}{l}\text { No. 79: Published in: Journal of Finance, "Foreign Speculators and } \\
\text { Emerging Equity Markets."v.22, iss. 2, 2000, pp. 565-613 }\end{array}$ & $\begin{array}{l}\text { Geert Bekaert and Campbell R. } \\
\text { Harvey }\end{array}$ & Aug. 1997 \\
\hline $\begin{array}{l}\text { No. 78: The Relationship Between Economic Factors and Equity } \\
\text { Markets in Central Europe }\end{array}$ & $\begin{array}{l}\text { Jan Hanousek and Randall K. } \\
\text { Filer }\end{array}$ & June 1997 \\
\hline $\begin{array}{l}\text { No. } 77 \text { Published in: Economics of Transition, "A Gini Decomposition } \\
\text { Analysis of Inequality in the Czech and Slovak Republics During the } \\
\text { Transition," Vol. 6, No.1, May 1998, pp. 23-46. }\end{array}$ & $\begin{array}{l}\text { Thesia I. Garner and Katherine } \\
\text { Terrell }\end{array}$ & May 1998 \\
\hline $\begin{array}{l}\text { No. 76: China's Emerging Market for Property Rights: Theoretical and } \\
\text { Empirical Perspectives }\end{array}$ & $\begin{array}{l}\text { Gary H. Jefferson and Thomas G. } \\
\text { Rawski }\end{array}$ & June 1997 \\
\hline $\begin{array}{l}\text { No. 75b: Test of Permanent Income Hypothesis on Czech Voucher } \\
\text { Privatization }\end{array}$ & Jan Hanousek and Zdenek Tima & Oct. 1997 \\
\hline $\begin{array}{l}\text { No. 74: Determinants of Performance of Manufacturing Firms in Seven } \\
\text { European Transition Economies }\end{array}$ & $\begin{array}{l}\text { Stijn Claessens, Simeon Djankov, } \\
\text { and Gerhard Pohl }\end{array}$ & Feb. 1997 \\
\hline $\begin{array}{l}\text { No. } 73 \text { Published in: Economics of Transition, "The Restructuring of } \\
\text { Large Firms in Slovak Republic." Vol. 6, No. 1, May 1998, pp. 67-85 }\end{array}$ & $\begin{array}{l}\text { Simeon Djankov and Gerhard } \\
\text { Pohl }\end{array}$ & May 1998 \\
\hline $\begin{array}{l}\text { No. 72: Law, Relationships, and Private Enforcement: Transactional } \\
\text { Strategies of Russian Enterprises }\end{array}$ & $\begin{array}{l}\text { Kathryn Hendley, Peter Murrell, } \\
\text { and Randi Ryterman }\end{array}$ & Nov. 1998 \\
\hline $\begin{array}{l}\text { No. 71: Giving Credit Where Credit Is Due: The Changing Role of } \\
\text { Rural Financial Institutions in China }\end{array}$ & $\begin{array}{l}\text { Albert Park, Loren Brandt, and } \\
\text { John Giles }\end{array}$ & Mar. 1997 \\
\hline $\begin{array}{l}\text { No. 70: Privatization Versus Competition: Changing Enterprise } \\
\text { Behavior in Russia }\end{array}$ & John S. Earle and Saul Estrin & $\begin{array}{l}\text { Spring } \\
1997\end{array}$ \\
\hline $\begin{array}{l}\text { No. 69: Russian Managers under Storm: Explicit Reality and Implicit } \\
\text { Leadership Theories (A Pilot Exploration) }\end{array}$ & Igor Gurkov & Oct. 1998 \\
\hline $\begin{array}{l}\text { No. 68: The Political Economy of Central-Local Relations in China: } \\
\text { Inflation and Investment Controls During the Reform Era }\end{array}$ & Yasheng Huang & $\begin{array}{l}\text { Spring } \\
1997\end{array}$ \\
\hline $\begin{array}{l}\text { No. 67: Between Two Coordination Failures: Automotive Industrial } \\
\text { Policy in China with a Comparison to Korea }\end{array}$ & Yasheng Huang & $\begin{array}{l}\text { Spring } \\
1997\end{array}$ \\
\hline $\begin{array}{l}\text { No. } 66 \text { Published in: Post-Soviet Geography and Economics, "Red } \\
\text { Executives in Russia's Transition Economy." Vol. 27, No. 10, Nov. } \\
\text { 1996, pp. 633-651. }\end{array}$ & Susan J. Linz & Jan. 1997 \\
\hline $\begin{array}{l}\text { No. } 65 \text { Published in: Industrial and Corporate Change, "On the } \\
\text { Sequencing of Privatization in Transition Economies." Vol. 7, No. 1, } \\
1998 .\end{array}$ & $\begin{array}{l}\text { Gautam Ahuja and Sumit K. } \\
\text { Majumdar }\end{array}$ & Apr. 1997 \\
\hline
\end{tabular}




\begin{tabular}{|c|c|c|}
\hline $\begin{array}{l}\text { No. 64: Published in: Journal of Law and Economics, "Foreign } \\
\text { Ownership and Profitability: Property Rights, Control and the } \\
\text { Performance of Firms in Indian Industry" 42(1), Apr. 1999, pp. 209-38. }\end{array}$ & $\begin{array}{l}\text { Pradeep K. Chhibber and Sumit } \\
\text { K. Majumdar }\end{array}$ & Apr. 1997 \\
\hline No. 63: How Taxing Is Corruption on International Investors? & Shang-Jin Wei & Feb. 1997 \\
\hline $\begin{array}{l}\text { No. 62: What Can We Learn from the Experience of Transitional } \\
\text { Economies with Labour Market Policies? }\end{array}$ & Tito Boeri & 1997 \\
\hline $\begin{array}{l}\text { No. 61: Published in: Accounting Organizations and Society, } \\
\text { "Economic Transition, Strategy and the Evolution of Management } \\
\text { Accounting Practices: The Case of India" 24(5,6), Jul/Aug 1999, pp. } \\
\text { 379-412. }\end{array}$ & $\begin{array}{l}\text { Shannon W. Anderson and } \\
\text { William N. Lanen }\end{array}$ & Apr. 1997 \\
\hline $\begin{array}{l}\text { No. 60a: Enterprise Investment During the Transition: Evidence from } \\
\text { Czech Panel Data }\end{array}$ & Lubomír Lizal and Jan Svejnar & Dec. 1997 \\
\hline $\begin{array}{l}\text { No. 59: Published in: Journal of Law, Economics, and Organization, } \\
\text { "Institutional Environment, Community Government, and Corporate } \\
\text { Governance: Understanding China's Township-Village Enterprises." } \\
\text { 14(1), Apr. 1998, pages 1-23 }\end{array}$ & Jiahua Che and Yingyi Qian & Apr. 1997 \\
\hline No. 58: From the Grabbing Hand to the Helping Hand & Jiahua Che & June 2000 \\
\hline $\begin{array}{l}\text { No. 57: Published in: Brookings Papers on Economic Activity, "The } \\
\text { Unofficial Economy in Transition." 1: } 1998 .\end{array}$ & $\begin{array}{l}\text { Simon Johnson, Daniel } \\
\text { Kaufmann, and Andrei Schleifer }\end{array}$ & June 1997 \\
\hline No. 56: Taxes and Government Incentives: Eastern Europe vs. China & Roger H. Gordon and David D. Li & Apr. 1997 \\
\hline No. 55: Corruption and Reform & Susanto Basu and David Li & June 1996 \\
\hline $\begin{array}{l}\text { No. 54: Decentralization and the Macroeconomic Consequences of } \\
\text { Commitment to State-Owned Firms }\end{array}$ & Loren Brandt and Xiaodong Zhu & June 1997 \\
\hline $\begin{array}{l}\text { No. 53: Published in: The International Journal of Industrial } \\
\text { Organization, "Competitive Shocks and Industrial Structure: The Case } \\
\text { of Polish Manufacturing." Aug., 1999. . }\end{array}$ & $\begin{array}{l}\text { Pankaj Ghemawat and Robert E. } \\
\text { Kennedy }\end{array}$ & May 1997 \\
\hline $\begin{array}{l}\text { No. 52: Published in: The Quarterly Journal of Economics, "Insecure } \\
\text { Property Rights and Government Ownership of Firms." May, } 1998 .\end{array}$ & Jiahua Che and Yingyi Qian & May 1997 \\
\hline No. 51: Incentives, Scale Economies, and Organizational Form & $\begin{array}{l}\text { Eric Maskin, Yingyi Qian, and } \\
\text { Chenggang Xu }\end{array}$ & May 1997 \\
\hline $\begin{array}{l}\text { No. 50: Published in: Post-Soviet-Affairs, "End of the Tunnel? The } \\
\text { Effects of Financial Stabilization in Russia" Apr.-June 1997, pages 105- } \\
33\end{array}$ & $\begin{array}{l}\text { Barry W. Ickes, Peter Murrell, } \\
\text { and Randi Ryterman }\end{array}$ & Mar. 1997 \\
\hline $\begin{array}{l}\text { No. 49: The Evolution of Bank Credit Quality in Transition: Theory and } \\
\text { Evidence from Romania }\end{array}$ & $\begin{array}{l}\text { Enrico C. Perotti and Octavian } \\
\text { Carare }\end{array}$ & Oct. 1996 \\
\hline $\begin{array}{l}\text { No. 48: Where Do the Leaders Trade? Information Revelation and } \\
\text { Interactions Between the Segments of Czech Capital Markets }\end{array}$ & $\begin{array}{l}\text { Jan Hanousek and Libor } \\
\text { Nemecek }\end{array}$ & May 1997 \\
\hline $\begin{array}{l}\text { No. 47: Firms' Heterogeneity in Transition: Evidence from a Polish } \\
\text { Panel Data Set }\end{array}$ & $\begin{array}{l}\text { Irena Grosfeld and Jean-François } \\
\text { Nivet } \\
\text { Janet Mitchell }\end{array}$ & May 1997 \\
\hline No. 46: Strategic Creditor Passivity, Regulation, and Bank Bailouts & Janet Mitchell & May 1997 \\
\hline $\begin{array}{l}\text { No. 45a: Published in: Journal of Public Economics, "Tax Rights in } \\
\text { Transition Economies: A Tragedy of the Commons.” 76, 2000, pp. 369- } \\
397\end{array}$ & Daniel M. Berkowitz and Wei Li & Sept. 1997 \\
\hline $\begin{array}{l}\text { No. 44a: The Information Content of Stock Markets: Why do Emerging } \\
\text { Markets have Synchronous Stock Price Movements? (forthcoming in } \\
\text { the Journal of Financial Economics). }\end{array}$ & $\begin{array}{l}\text { Randall Morck, Bernard Yeung, } \\
\text { and Wayne Yu }\end{array}$ & Feb. 1999 \\
\hline $\begin{array}{l}\text { No. 43: Agency in Project Screening and Termination Decisions: Why } \\
\text { Is Good Money Thrown After Bad? }\end{array}$ & Chong-en Bai and Yijiang Wang & May 1997 \\
\hline $\begin{array}{l}\text { No. 42: Published in: Economics of Transition, "Channels of } \\
\text { Redistribution: Inequality and Poverty in the Russian Transition." Vol. } 7 \\
\text { (2) } 1999 .\end{array}$ & $\begin{array}{l}\text { Simon Commander, Andrei } \\
\text { Tolstopiatenko, and Ruslan } \\
\text { Yemtsov }\end{array}$ & May 1997 \\
\hline $\begin{array}{l}\text { No. 41: Published in: Economics of Transition, "Labour Market } \\
\text { Characteristics and Profitability: Econometric Analysis of Hungarian } \\
\text { Exporting Firms, 1986-1995" 6(1), May 1998, pages 145-62 }\end{array}$ & László Halpern and Gabor Korosi & May 1997 \\
\hline
\end{tabular}




\begin{tabular}{|c|c|c|}
\hline $\begin{array}{l}\text { No. 40: Published in: the Harvard Law Review, "The Tragedy of the } \\
\text { Anticommons: Property in the Transition from Marx to Markets." Jan. } \\
\text { 1998. }\end{array}$ & Michael Heller & Feb. 1997 \\
\hline No. 39: Privatization and Managerial Efficiency & $\begin{array}{l}\text { Olivier Debande and Guido } \\
\text { Friebel }\end{array}$ & May 1997 \\
\hline $\begin{array}{l}\text { No. } 38 \text { Published in: The Quarterly Journal of Economics, } \\
\text { "Disorganization." Vol. 112, No. 4, Nov. 1997, pp. 1091-1126. }\end{array}$ & $\begin{array}{l}\text { Olivier Blanchard and Michael } \\
\text { Kremer }\end{array}$ & Jan. 1997 \\
\hline $\begin{array}{l}\text { No. 37: Published in: Economics of Transition, "Transition and the } \\
\text { Output Fall." } 7(1), 1999 \text {, pages 1-28. }\end{array}$ & $\begin{array}{l}\text { Gérard Roland and Thierry } \\
\text { Verdier }\end{array}$ & Mar. 1997 \\
\hline $\begin{array}{l}\text { No. 36: Restructuring an Industry During Transition: A Two-Period } \\
\text { Model }\end{array}$ & Richard Ericson & Sept. 1996 \\
\hline No. 34: The East-West Joint Venture: BC Torsion Case Study & $\begin{array}{l}\text { Sonia Ferencikova and Vern } \\
\text { Terpstra }\end{array}$ & Dec. 1998 \\
\hline $\begin{array}{l}\text { No. } 33 \text { Published in: Journal of Comparative Economics, "Quantifying } \\
\text { Price Liberalization in Russia." Vol. 26, No. 4, Dec. 1998, pp. 735-737. }\end{array}$ & $\begin{array}{l}\text { Daniel Berkowitz, David DeJong, } \\
\text { and Steven Husted }\end{array}$ & Dec. 1998 \\
\hline No. 32: What Can North Korea Learn from China's Market Reforms? & John McMillan & Sept. 1996 \\
\hline $\begin{array}{l}\text { No. 31: Published in: China-Economic-Review, "Towards a Model of } \\
\text { China as a Partially Reformed Developing Economy Under a } \\
\text { Semifederalist Government." 9(1), Spring 1998, pages 1-23. }\end{array}$ & Yijiang Wang and Chun Chang & Mar. 1997 \\
\hline $\begin{array}{l}\text { No. 30: Convergence in Output in Transition Economies: Central and } \\
\text { Eastern Europe, 1970-1995 }\end{array}$ & Saul Estrin and Giovanni Urga & Feb. 1997 \\
\hline $\begin{array}{l}\text { No. 29: Published in: Economics of Transition, "Altered Band and } \\
\text { Exchange Volatility." Volume 6, no. 1, 1998, 173-181. }\end{array}$ & Evzen Kocenda & Mar. 1997 \\
\hline $\begin{array}{l}\text { No. 28: Published in: Quarterly Journal of Economics, "Public Versus } \\
\text { Private Ownership of Firms: Evidence from Rural China." Volume 113, } \\
\text { no. 3, Aug. 1998, 773-808. }\end{array}$ & Hehui Jin and Yingyi Qian & Jan. 1997 \\
\hline $\begin{array}{l}\text { No. 27: East-West Joint Ventures in a Transitional Economy: The Case } \\
\text { of Slovakia }\end{array}$ & Sonia Ferencikova & Mar. 1997 \\
\hline $\begin{array}{l}\text { No. 26: Published in Economic Analysis "Behavior of a Slovenian Firm } \\
\text { in Transition" Vol. 1, no. 1, 1998, 57-73. }\end{array}$ & Janez Prasnikar & Feb. 1997 \\
\hline $\begin{array}{l}\text { No. 25: Cultural Encounters and Claims to Expertise in Postcommunist } \\
\text { Capitalism }\end{array}$ & Michael D. Kennedy & Feb. 1997 \\
\hline $\begin{array}{l}\text { No. 24: ZVU a.s.: Investment Funds on the Board of Directors of an } \\
\text { Engineering Giant }\end{array}$ & Tory Wolff & Aug. 1995 \\
\hline $\begin{array}{l}\text { No. 23: The Role of Investment Funds in the Czech Republic (joint } \\
\text { publication with Czech Management Center) }\end{array}$ & Dusan Triska & June 1996 \\
\hline $\begin{array}{l}\text { No. 22: Czech Investment Fund Industry: Development and Behaviour } \\
\text { (joint publication with Czech Management Center) }\end{array}$ & Richard Podpiera & May 1996 \\
\hline $\begin{array}{l}\text { No. 21: Restructuring of Czech Firms: An Example of Gama, a.s. (joint } \\
\text { publication with Czech Management Center) }\end{array}$ & Antonin Bulin & June 1996 \\
\hline $\begin{array}{l}\text { No. 20: YSE Funds: A Story of Czech Investment Funds (joint } \\
\text { publication with Czech Management Center) }\end{array}$ & Michal Otradovec & Nov. 1995 \\
\hline $\begin{array}{l}\text { No. 19: První Investicni a.s., The First Investment Corporation (joint } \\
\text { publication with Czech Management Center) }\end{array}$ & Jaroslav Jirasek & Aug. 1995 \\
\hline $\begin{array}{l}\text { No. 18: PPF a.s., The First Private Investment Fund (joint publication } \\
\text { with Czech Management Center) }\end{array}$ & Michal Otradovec & Nov. 1995 \\
\hline $\begin{array}{l}\text { No. } 17 \text { Published in: Post-Soviet Geography and Economics, "Russia's } \\
\text { Managers in Transition: Pilferers or Paladins?" 37(7) (Sept. 1996), pp. } \\
\text { 397-426. }\end{array}$ & Susan J. Linz and Gary Krueger & Nov. 1996 \\
\hline $\begin{array}{l}\text { No. 16: Banks in Transition-Investment Opportunities in Central } \\
\text { Europe and Russia, Edited Transcript from } 31 \text { May } 1996 \text { Conference in } \\
\text { New York City }\end{array}$ & $\begin{array}{l}\text { With commentary and edited by } \\
\text { Anna Meyendorff }\end{array}$ & Jan. 1997 \\
\hline $\begin{array}{l}\text { No. 15: Marketing in Transitional Economies: Edited Transcript \& } \\
\text { Papers from } 1 \text { Apr. } 1996 \text { Conference in Ann Arbor, Michigan }\end{array}$ & $\begin{array}{l}\text { Compiled by The Davidson } \\
\text { Institute }\end{array}$ & Dec. 1996 \\
\hline
\end{tabular}


Davidson Institute Working Papers are available at: www.wdi.bus.umich.edu

\begin{tabular}{|c|c|c|c|}
\hline \multicolumn{2}{|c|}{$\begin{array}{l}\text { No. 14: Pensions in the Former Soviet Bloc: Problems and Solutions. } \\
\text { Published by Council on Foreign Relations. "The Coming Global } \\
\text { Pension Crisis" New York, } 1997\end{array}$} & Jan Svejnar & Nov. 1996 \\
\hline \multicolumn{2}{|c|}{$\begin{array}{l}\text { No. 13: Enterprise Restructuring and Performance in the Transition. } \\
\text { Forthcoming in Financial Systems in Transition: The Design of } \\
\text { Financial Systems in Central Europe eds. Anna Meyendorff and Anjan } \\
\text { Thakor. }\end{array}$} & $\begin{array}{l}\text { Lubomir Lizal, Miroslav Singer, } \\
\text { and Jan Svejnar }\end{array}$ & Dec. 1996 \\
\hline \multicolumn{2}{|c|}{$\begin{array}{l}\text { No. } 12 \text { Published in: Journal of International Marketing, "Executive } \\
\text { Insights: Marketing Issues and Challenges in Transitional Economies." } \\
\text { Vol. 5, No. 4, 1997, pp. 95-114. Also published in: Marketing Issues in } \\
\text { Transitional Economies ed. Rajeev Batra. }\end{array}$} & Rajeev Batra & Apr. 1997 \\
\hline \multicolumn{2}{|c|}{$\begin{array}{l}\text { No. 11: Worker Trust and System Vulnerability in the Transition from } \\
\text { Socialism to Capitalism }\end{array}$} & Andrew Schotter & Aug. 1996 \\
\hline \multicolumn{2}{|c|}{$\begin{array}{l}\text { No. } 10 \text { Published in: Comparative Economic Studies, "Russian Firms in } \\
\text { Transition: Champions, Challengers, and Chaff." Vol. 39, No.2, } \\
\text { Summer 1997, pp. 1-36. }\end{array}$} & Susan J. Linz & July 1996 \\
\hline \multicolumn{2}{|c|}{$\begin{array}{l}\text { No. 9: Corporate Debt Crisis and Bankruptcy Law During the } \\
\text { Transition: The Case of China }\end{array}$} & David D. Li and Shan Li & Dec. 1995 \\
\hline \multicolumn{2}{|c|}{$\begin{array}{l}\text { No. } 8 \text { Published in: Journal of Comparative Economics, "A Theory of } \\
\text { Ambiguous Property Rights in Transition Economies: The Case of the } \\
\text { Chinese Non-State Sector." Vol. 23, No. 1, Aug. 1996, pp. 1-19. }\end{array}$} & David D. Li & June 1996 \\
\hline \multicolumn{2}{|c|}{$\begin{array}{l}\text { No. 7: The Foreign Economic Contract Law of China: Cases and } \\
\text { Analysis }\end{array}$} & Dong-lai Li & June 1993 \\
\hline \multicolumn{2}{|c|}{$\begin{array}{l}\text { No. 3: Bank Privatization in Hungary and the Magyar Kulkereskedelmi } \\
\text { Bank Transaction }\end{array}$} & $\begin{array}{l}\text { Roger Kormendi and Karen } \\
\text { Schnatterly }\end{array}$ & May 1996 \\
\hline $\begin{array}{l}\text { Replacing No. 1: Journal of Comparative Economics } \\
\text { Symposium on "Bank Privatization in Central Europe and } \\
\text { Russia." Vol. 25, No. 1, Aug. } 1997 .\end{array}$ & \multicolumn{2}{|c|}{$\begin{array}{l}\text { "Bank Privatization in Transitional } \\
\text { Economies," Roger Kormendi and Edward } \\
\text { Snyder. }\end{array}$} & Aug. 1997 \\
\hline $\begin{array}{l}\text { Replacing No. 2: Journal of Comparative Economics } \\
\text { Symposium on "Bank Privatization in Central Europe and } \\
\text { Russia." Vol. 25, No. 1, Aug. } 1997 .\end{array}$ & \multicolumn{2}{|c|}{$\begin{array}{l}\text { "Transactional Structures of Bank } \\
\text { Privatizations in Central Europe and } \\
\text { Russia," Anna Meyendorff and Edward A. } \\
\text { Snyder. }\end{array}$} & Aug. 1997 \\
\hline $\begin{array}{l}\text { Replacing No. 4: Journal of Comparative Economics } \\
\text { Symposium on "Bank Privatization in Central Europe and } \\
\text { Russia." Vol. 25, No. 1, Aug. } 1997 .\end{array}$ & \multicolumn{2}{|c|}{$\begin{array}{l}\text { "Bank Privatization in Poland: The Case of } \\
\text { Bank Slaski," Jeffery Abarbaness and John } \\
\text { Bonin. }\end{array}$} & Aug. 1997 \\
\hline $\begin{array}{l}\text { Replacing No. 5: Journal of Comparative Economics } \\
\text { Symposium on "Bank Privatization in Central Europe and } \\
\text { Russia." Vol. 25, No. 1, Aug. } 1997 .\end{array}$ & \multicolumn{2}{|c|}{$\begin{array}{l}\text { "Bank Privatization in Post-Communist } \\
\text { Russia: The Case of Zhilsotsbank," Jeffery } \\
\text { Abarbanell and Anna Meyendorff }\end{array}$} & Aug. 1997 \\
\hline $\begin{array}{l}\text { Replacing No. 6: Journal of Comparative Economics } \\
\text { Symposium on "Bank Privatization in Central Europe and } \\
\text { Russia." Vol. 25, No. 1, Aug. } 1997 .\end{array}$ & \multicolumn{2}{|c|}{$\begin{array}{l}\text { "The Czech Republic's Commercial Bank: } \\
\text { Komercni Banka," Edward A. Snyder and } \\
\text { Roger C. Kormendi. }\end{array}$} & Aug. 1997 \\
\hline
\end{tabular}

